\title{
PODOABE DIN AUR DIN PERIOADA ROMANĂ TÂRZIE DESCOPERITE ÎN ZONA COMUNEI OSTROV, JUDEȚUL CONSTANȚA
}

ALEXANDRU ARBUNESCU

\section{LATE ROMAN GOLD JEWELRY FOUND AT OSTROV, CONSTANȚA COUNTY}

The article approaches an unpublished set of jewelry found almost seventy years ago, on $12^{\text {th }}$ of January 1949, by three peasants from Ostrov, Constanța County, into a late Roman sarcophagus. The authorities succeeded to retrieve a golden crossbow brooch, a pair of golden earrings, five golden amphora shaped beads from a necklace, 18 golden drop shaped and rhombic cassettes with inlayed garnets and green glass paste and 15 thin sheets of gold, probably fragments of damaged cassettes. Unfortunately, the sarcophagus and the rest of the items were not recovered.

Most probably the sarcophagus and the rich funerary inventory belonged to a high ranked Roman officer from Legio XI Claudia which was headquartered at Durostorum (Silistra, Bulgaria, nearby Ostrov, Romania) between $2^{\text {nd }}-6^{\text {th }}$ centuries CE.

Considering the typological and stylistical analogies, we assume that the items are dating from the middle of $3^{\text {rd }}$ century - beginning of $4^{\text {th }}$ century CE. Some of the artifacts may have been produced in local workshops, some have been probably imported from Eastern provinces of the Roman Empire.

KEYWORDS: Ostrov, Durostorum, sarcophagus, roman, brooch.

CUVINE CHEIE: Ostrov, Durostorum, sarcofag, roman, fibulă.

\section{ISTORICUL DESCOPERIRII}

În urmă cu aproape 70 de ani, în ziua de 11 mai 1949, intra în patrimoniul Muzeului Național de Antichități, prin transfer de la Banca de Stat a Republicii Populare România, conform procesului verbal nr. 257/1949, un set de podoabe din aur romane târzii constituit din: o fibulă, o pereche de cercei, 18 aplice în formă de casete (două cordiforme, 12 în formă de picătură, patru rombice), 15 foi subţiri din aur (şapte rombice, trei în formă de lacrimă, cinci fragmentare), cinci mărgele tubulare şi un buton mic din aur.

Piesele au fost apoi transferate Muzeului de Istorie al Republicii Socialiste România prin procesul verbal nr. 2/1971, conform Deciziei Academiei de Științe Sociale și Politice a Republicii Socialiste România, emisă în urma Hotărârii Consiliului de Miniștri nr. 294/1970.

Potrivit consemnărilor din ziua de 13 mai 1949, de la nr. crt. 43 din Registrul de inventar al Muzeului Naţional de Antichități, podoabele au fost descoperite întâmplător, în ziua de 12 ianuarie 1949, de trei țărani, într-un sarcofag roman, pe raza comunei Ostrov, județul Constanța.

Sarcofage și fragmente de sarcofage datând din secolele II-IV p. Chr. au fost descoperite în perimetrul necropolelor de la Durostorum, la vest, sud și est de castrul roman, respectiv de canabae, pe locul actualului oraș Slistra din Bulgaria și la vest și sud de vicus, situat la aproximativ $3 \mathrm{~km}$ sudvest, pe teritoriul românesc, în vecinătatea comunei Ostrov ${ }^{1}$.

Între secolele II-IV p. Chr. castrul roman de la Durostorum, unde a fost staționată Legio XI Claudia încă din anul 106 p. Chr., în timpul domniei împăratului Traian (98-117 p. Chr.), canabae-le și așezarea civilă de tip vicus, au cunoscut o rapidă dezvoltare atingând un nivel ridicat de prosperitate, dovadă fiind altarele și termele, construcțiile civile, tezaurele monetare și mormintele cu inventare funerare bogate. În timpul împăratului Antoninus Pius (138-161 p. Chr.), așezarea civilă constituită în apropierea castrului a primit gentiliciu imperial, fiind cunoscută sub denumirea de Canabae Aeliae Legionis XI Claudiae. Mai târziu, în timpul domniei împăratului Marcus Aurelius (161-180 p. Chr.), a dobândit statutul de Municipium Aurelium Durostorum, beneficiind astfel de toate consecințele

\footnotetext{
${ }^{1}$ Donevski 2009, 125, fig. 22.
} 
avantajoase și devenind un centru militar și urban de importanţă majoră al provinciei romane Moesia Inferior ${ }^{2}$, divizată mai târziu în Moesia Secunda și Scythia Minor.

Un sarcofag datat în prima jumătate a secolului al III-lea p. Chr. descoperit, probabil de profesorul Pericle Papahagi, în comuna Ostrov, județul Constanța, care a fost expus în curtea prefecturii din Silistra până în anul 1940, când a fost adus la Călăraşi de Gheorghe Diaconu, face parte acum din patrimoniul Muzeului Dunării de Jos din Călăraşi (inv. 11395) ${ }^{3}$. Tot în lapidarium-ul din curtea muzeului din Călărași este amplasat și un capac de sarcofag, iar la Muzeul de Istorie Națională și Arheologie Constanța se află un fragment de sarcofag, care provine tot din zona comunei Ostrov și este datat în secolul al III-lea p. Chr. de Maria Alexandrescu Vianu, care îl consideră un produs al unui atelier local ${ }^{4}$.

Pericle Papahagi relatează într-o notă din primul număr al revistei „Dunărea” şi despre un sarcofag prăbușit în apele fluviului, în anul $1922^{5}$.

Un alt sarcofag roman, ornamentat pe latura lungă cu doi Erotes susținând o tabula ansata, este amplasat în lapidarium-ul Muzeului de Arheologie din Silistra (Durostorum). Tot acolo mai este expus unul similar, cu acrotere nedecorate, descoperit la intersecția străzilor Janko Todorov cu General Kolev. Sarcofagul, care a aparținut unui copil, a fost datat în a doua jumătate a secolului al IIlea p. Chr. pe baza unor monede cu portretele împăratului Antoninus Pius (138-161 p. Chr.) şi fiicei sale, Faustina Minor, soția împăratului Marcus Aurelius (161-180 p. Chr.) ${ }^{6}$.

La Silistra, au fost descoperite morminte cu sarcofage la nord și est de perimetrul castrului roman, datate prin monede din a doua jumătate a secolului al II-lea p. Chr, precum și la sud-est, pe străzile Makarenko și V. Kolarov cu un inventar ce include o mare varietate de obiecte și podoabe din bronz, argint și aur?

O descoperire neobișnuită o constituie mormântul cu un sarcofag din plumb și un car cu patru roți alături, cu un inventar funerar excepțional de bogat - două spate cu teci din lemn decorate cu plăci din argint aurit și incrustații de pietre prețioase, aplice de harnașament din aur, împreună cu o fibulă cruciformă din aur și un inel cu gemă. Bogăţia frapantă a inventarului mormântului, datat în secolul al IV-lea p. Chr., indică poziția socială înaltă al defunctului ${ }^{8}$.

Informațiile privitoare la condițiile descoperirii pieselor ce compuneau inventarul sarcofagului roman de la Ostrov, menționate în procesul verbal de la Muzeul Național de Antichități, sunt laconice. Prin urmare este imposibil de precizat dacă sarcofagul mai există sau din care sarcofag, dintre cele păstrate, provin podoabele predate de cei trei țărani autorităților în anul 1949. Inventarul, parțial deteriorat și foarte probabil incomplet, este inedit.

\section{INVENTARUL FUNERAR. ÎNCADRARE CRONOLOGICĂ, PROVENIENȚĂ, ANALOGII}

Piesa centrală a descoperirii de la Ostrov este fibula cruciformă. Axul transversal al fibulei este din bară din cupru cu secţiune pătrată, acoperită cu foaie din aur, cu butoni la extremități. Pe braţ, la mijlocul distanței dintre butoni, este lipită o placă semicirculară din aur, cu marginea bordată cu decor de linii incizate. Arcul fibulei, din bandă groasă, cu secțiune dreptunghiulară, curbată, din aur, este ornamentat prin inciziare cu o linie mediană, longitudinală, pe care sunt dispuse triunghiuri mici, suprapuse și aliniate cu vârful în jos, incrustate cu niello. Piciorul fibulei, în formă de prismă semicirculară, cu pereții din tablă din aur, este prevăzut la partea laterală cu o deschizătură pentru acul fibulei, care lipsește (MNIR inv. 9440).

Subsecvent fibulei celtice, preluată de romani, tipul de fibulă cruciformă, sau în formă de arbaletă, aşa cum mai este denumit în literatura de specialitate engleză (crossbow fibula sau crossbow brooch), franceză (fibule en arbalète) și germană (armbrustfibel), era un ornament exclusiv masculin și militar. Folosită pentru fixarea paludamentum-ului, era purtată de ofițerii romani de rang superior pe umărul drept,

\footnotetext{
2 Atanasov 2007, 447; Damian, Bâltâc 2007, 62-63; Bâltâc 2011, 92-93.

${ }^{3}$ Stirbulescu 2007, 285.

${ }^{4}$ Alexandrescu-Vianu 1970, 298-299, nr. 33, fig. 12; Știrbulescu 2007, 287.

${ }^{5}$ Știrbulescu 2007, 284.

${ }^{6}$ Ivanov, Atanasov, Donevski 2006, 245, fig. 4; Știrbulescu 2007, 287-288, Donevski 2009, 126, fig 25.

${ }^{7}$ Ivanov, Atanasov, Donevski 2006, 261; Donevski 2009, 110.

${ }^{8}$ Donevski 2009, 111
} 
cu piciorul fibulei orientat în sus, având cu deosebire, pe lângă funcția de prindere a veșmântului, pe aceea de insignia, de accesoriu al unei ținute oficiale caracteristice unei poziții sociale distincte 9 .

Larg răspândită în epocile romană-târzie și bizantină-timpurie, fibula cruciformă derivă dintr-o varietate premergătoare a fibulei romane din secolele II-III p. Chr. devenind prevalentă la sfârșitul secolului al III-lea și începutul secolului al IV-lea p. Chr. Un exemplu este fibula cruciformă din aur, cu iscripția „HERCULI AUGUSTE SEMPER VINCAS” de la The Metropolitan Museum of Art, New York, datată în primul deceniu al secolului al IV-lea p. Chr, descoperită la Arezzo, în Italia, și achiziționată prin subscripție de la Samuel T. Baxter în $1895^{10}$. Andrew Oliver Jr., consideră că inscripția se referă la Constantin cel Mare, care a folosit titlul de „Herculi Auguste” între anii 307-310 p. Chr., după care 1-a abandonat pe Hercules ca protector, adoptându-l pe Sol Invictus în locul acestuia. Andrew Oliver prezumă că fibula a aparținut unui soldat cu rang înalt de sub comanda lui Constantin şi că datează din perioada cuprinsă între acei ani ${ }^{11}$.

O fibulă cruciformă similară, de la British Museum, a fost descoperită la Odiham, districtul Hart, Hampshire și datează din secolul al IV-lea p. Chr. Fibula, din aur, cu axul transversal hexagonal, cu butoni în formă de cupolă la extremități și unul în centru, are arcul cvadrangular, decorat cu același motiv incizat de triunghiuri suprapuse, incrustate cu niello, prezent și pe fibula cruciformă de la Ostrov $^{12}$. Tehnica nielajului, consta în aplicarea unei paste de culoare neagră obținută dintr-un compus de pulbere de sulfură de argint, cupru și plumb supusă unui proces de încălzire ușoară până la o temperatură de sub punctul de topire. Folosită de vascularii încă din secolul al II-lea p. Chr. în ornamentarea vaselor din aur și argint, tehnica nielajului a fost uzitată și în decorarea podoabelor romane târzii de la sfârșitul secolului al III-lea și începutul secolului al IV-lea p. Chr. ${ }^{13}$

La Muzeul de Arheologie din Silistra este expusă, împreună cu inventarul impresionant al mormântului cu sarcofag din plumb și car cu patru roți, o fibulă cruciformă cu axul transversal octogonal, cu doi butoni sferici la terminații și unul la mijloc, al cărei arc, puternic curbat, este decorat prin incizare cu motive incrustate cu niello. Fibula, asemănătoare celei de la Ostrov, datează din secolul al IV-lea p. Chr. ${ }^{14}$

În Serbia, la Gamizgrad (Romuliana Felix), au fost descoperite mai multe fibule cruciforme dintre care se remarcă un exemplar aflat la Muzeul Național din Zaječar (inv. nr. C 1137/05). Fibula cruciformă, cu butoni la extremitățile axului transversal și arcul de secțiune trapezoidală, ornamentat cu o bandă decorată cu o suită de pătrate incizate, incrustate cu niello, a fost datată de Sofija Petković în perioada Tetrarhiei, la sfârșitul secolului al III-lea - începutul secolului al IV-lea p. Chr. ${ }^{15}$

Tot în Serbia, la Muzeul Național din Belgrad (Singidunum), există o fibulă din aur asemănătoare (inv. 629/II), datată între anii 290-320 p. Chr., locul descoperirii fiind necunoscut. Arcul semicircular are secțiunea trapezoidală iar axul transversal, de secțiune hexagonală, este prevăzut cu butoni sferici la capete și o placă semicirculară, bordată de un fir pseudo-torsionat, la mijloc, între butoni. Piciorul fibulei este scurt, ornat cu decor de linii incizate ${ }^{16}$.

O analogie mai apropiată a fibulei cruciforme de la Ostrov este cea descoperită în necropola romană de la Tirighina-Bărboși, Galați, județul Galați, în mormântul M7, unul dintre cele 16 morminte descoperite într-un tumul la sud de DN 25 și la circa $350 \mathrm{~m}$. vest de castrul roman. Fibula are axul transversal tubular, cu doi butoni la extremități și o placă semicirculară între butoni, asemeni fibulei de la Ostrov. Arcul curbat este decorat prin incizare cu un șir de pătrate incrustate cu niello, și inscripționat pe o latură cu litere latine „INNO[CENS]”. Piesa a fost datată în secolul al III-lea p. Chr. pe baza a trei monede din bronz din timpul împăratului Claudius al II-lea Goticul 268-270, care fac parte din inventarul aceluiași mormânt ${ }^{17}$.

\footnotetext{
9 Deppert-Lippitz 2000, 41-42; Allison 2013, 71,74.

${ }^{10}$ Higgins 1980, 185, pl. 63 B.

${ }^{11}$ Oliver 1966, 284, fig. 31.

${ }^{12}$ Marshall 1911, 337, pl. LXII, nr. 2858; Deppert-Lippitz 2000, 43, fig.4.

${ }^{13}$ Higgins 1980, 26-27.

${ }^{14}$ Donevski 2009, 111.

${ }^{15}$ Petković 2010, 127, fig. 8, cat. 9, tip 34 A 2.

${ }^{16}$ Popović 1996, 145-146, fig.5 II, 193, cat.147.

${ }^{17}$ Ilie 2014, 461, fig. 106.3.1.
} 
Într-un studiu taxonomic referitor la fibulele cruciforme, Emilie Riha le clasifică pe cele în formă de arbaletă de la Römermuseum din Augst, descoperite la Colonia Augusta Raurica (Augst și Kaiseraugst, Elveția), în tipul 6.4, varianta 7 și le datează în perioada cuprinsă între secolele I-IV p. $\mathrm{Chr}^{18}$.

Fibulele cruciforme, tipul cel mai comun de fibule romane, au avut o foarte largă răspândire de-a lungul Rinului și limes-ului danubian în secolele II-IV p. Chr. Variante ale acestui tip ajung să fie bine reprezentate și pe limes-ul oriental începând cu secolul al III-lea p. Chr., relevante în acest sens fiind exemplarele de la muzeul din Gaziantep, Turcia ${ }^{19}$.

Similitudinile tipologice, stilistice și maniera de execuție conduc la încadrarea cronologică a fibulei de la Ostrov între sfârșitul secolului al III-lea și începutul secolului al IV-lea p. Chr.

Din inventarul sarcofagului de la Ostrov, face parte și o pereche de cercei din aur cu terminația în formă de rozetă cu șase petale, din bară din aur de secțiune cvasi-triunghiulară, lipită pe o placă transversală, rectangulară, din aur, prevăzută cu două orificii. Printre cele două perforații este petrecut un fir din sârmă subțire de aur, la unul dintre cercei, iar la celălalt un fir realizat din bandă îngustă răsucită din aur. Probabil prin aceste fire era fixată în monturile cerceilor câte o piatră, care nu s-a mai păstrat. Pe spatele plăcii este lipită toarta, din sârmă din aur, în forma literei „S” (MNIR inv. 94389439).

De-a lungul întregii perioade romane, cerceii au fost unele dintre cele mai răspândite şi apreciate podoabe. Avându-și originile în Orient, au devenit, pentru multă vreme, genul de podoabe preferate de femei din stări sociale diferite. Aspectul lor relevă o proeminentă componentă elenistică, influențele culturale est-mediteraneene fiind evidente la artefactele meșterilor aurari romani (barbaricarii) în secolele II-IV p. Chr. În decursul timpului au suferit transformări care au constat în adăugarea de elemente noi sau în dezvoltarea de noi tehnici decorative, care să corespundă schimbărilor generate de stil și modă într-o anumită epocă. Astfel, expansiunea Imperiului roman, dezvoltarea atelierelor autohtone, interpretarea locală a anumitor modele, au avut un impact semnificativ ducând la o largă difuziune și popularitate a formelor elenistico-romane. Diferența între cerceii romani (inaures) și cei din epocile anterioare consistă, cu precădere, începând din perioada imperială, în folosirea preponderentă a pietrelor semiprețioase variat colorate, a pastei de sticlă și a perlelor, conferindu-le un efect coloristic foarte viu. Stilul policrom, ca reflectare a modei în rândul populației înstărite a devenit foarte popular în secolele II-III p. Chr. Marcând statutul femeilor romane, prețioasele podoabe erau tezaurizate și transmise în familie de la o generație la alta ${ }^{20}$.

Derivat din modelele elenistice, tipul de cercei cu cârlig din fir din aur în forma literei „S”, cu terminații în rozete hexagonale și cu monturi de pietre prețioase sau semiprețioase ori pastă de sticlă este caracteristic secolelor II-III p. Chr. Analogii pentru acest tip există la Muzeul Național din Belgrad, Šarkamen, Intercisa (Dunaujváros) şi Römisch-Germanisches Zentralmuseum din Mainz ${ }^{21}$. Reprezentarea unei tinere femei romane purtând cercei de acest tip pe o frescă a unui mormânt pictat de la Viminacium (Kostolac, Serbia) datat în secolul al IV-ea p. Chr. sugerează prelungirea perioadei în care această variantă de podoabă s-a aflat în $u^{22}$.

La Aquincum (Budapesta) a fost descoperit un număr mare de podoabe romane catalogate riguros de Facsády Annamária. Între ele, un cercel cu toarta în forma literei „S” și montura formată dintr-o ramă circulară, cu o piatră prismatică, hexagonală în mijloc, fixată printr-un fir din aur ce o străpunge longitudinal, similar modului de prindere a pietrelor care, probabil erau montate pe cerceii din aur de la Ostrov, dar care nu se mai păstrează, datează din secolul al III-lea p. Chr. O altă pereche de cercei din aur de la Aquincum, cu smaralde fixate printr-o sârmă subțire într-o montură constituită dintr-o ramă în formă de rozetă, se încadrează cronologic tot în secolul al III-lea p. Chr. ${ }^{23}$

Asemănătoare pieselor de la Ostrov este și o pereche de cercei din aur din Colecția Muzeului Național de Arheologie din Sofia (inv. nr. 4572/a-b) datată în secolele II-III p. Chr. Cerceii au cârligul din sârmă de aur în forma literei „S”, cu o rozetă hexagonală, dublă, din foaie din aur la capăt. În mijlocul rozetei este fixată o piatră de culoare verde în formă de prismă, cu un orificiu cilindric

\footnotetext{
${ }^{18}$ Riha 1994, 145, nr. 2725-2727, tip 6.4, varianta 7.

${ }^{19}$ Bulgan, Feugère 2007, 218.

${ }^{20}$ Popović 1996, 110-111; Milovanović 2004, 131.

${ }^{21}$ Milovanović 2004, 136, pl. 4 tip Vc; p. 137, pl. 5 tip Vc și Vd; p.140, Planșa 5, tip Vc.

${ }^{22}$ Milovanović 2004, 141.

${ }^{23}$ Facsády 2009, 76, cat. 280, 122, cat. 281.
} 
longitudinal prin care trece un fir din aur. De rozetă sunt suspendate trei pandantive din sârme pseudogranulate cu perle și pietre prismatice la terminații ${ }^{24}$.

Într-o clasificare a podoabelor romane de la Muzeul Național din Belgrad, Ivana Popović datează cerceii cu cârlig în forma literei „S”, cu monturi de pietre fixate prin fire din aur, descoperiți în necropolele de la Viminacium (Kostolac), între începutul secolului al II-lea și sfârșitul secolului al IIIlea p. Chr., în timp ce piesele încadrate în același tip, de la muzeul din Mainz, au fost în uz în secolele III-IV p. Chr. ${ }^{25}$

Dintre piesele descoperite de cei trei țărani într-un sarcofag, la Ostrov, s-au mai păstrat și cinci mărgele tubulare din foaie din aur în formă de amforetă. Mărgelele sunt globulare, cu extremitățile cilindrice, evazate progresiv la extremități și ușor răsfrânte spre exterior, decorate în zona mediană cu patru alveole concave, bordate de cercuri canelate (MNIR inv. 9459-9463).

Tradiția producerii mărgelelor și pandantivelor în formă de vase (amforete), originară din aria culturală egeeană, a continuat oarecum la scară mai mică în secolele II-IV p. Chr. prin activitatea centrelor locale ale căror artizani erau elenofoni sau emigranți originari din provinciile estice ale imperiului, ori meșteri autohtoni, care produceau forme decorative consacrate, cu puternice influențe elenistice, încă din epoca pre-romană.

În Bulgaria, regiunea Vrața, la Mezdra, au fost descoperite împreună cu o monedă din bronz din timpul lui Constantin cel Mare cinci mărgele asemănătoare celor de la Ostrov, dar fără decorul central de alveole mărginite de cercuri canelate. Au fost datate pe baza analogiilor, fără a lua în considerare moneda, la mijlocul secolului al III-lea p. Chr. Piesele fac parte din colecția Muzeului Naţional de Arheologie din Sofia (inv. nr. 6841) ${ }^{26}$.

La Jagodin Mala, Niș (Naissus), cu ocazia excavațiilor de la blocul „Benetton” din anul 2012, au fost descoperite trei coliere cu mărgele din foaie din aur similare, datate de Gordana Jeremić în secolul al IV-lea p. Chr. Piesele sunt expuse la Muzeul Național din Niș. Unul dintre coliere (inv. 1136/R), descoperit în mormântul nr. 16, este compus din 16 mărgele globulare în zona mediană, cu terminațiile cilindrice ușor evazate la extremități, altul (inv. 1183/R) provine din inventarul mormântului nr. 66 și consistă din mărgele din foaie din aur, asemănătoare celor de la Ostrov, care alternează cu mărgele din sticlă verde în formă de prismă hexagonală. Din al treilea colier (inv. 1156/R), descoperit în mormântul nr. 37, s-au păstrat numai șapte perle globulare, una dintre ele fiind ornamentată cu cinci caneluri orizontale ${ }^{27}$.

În colecția Muzeului Național din Belgrad se află un colier (inv. 6411 II) păstrat parțial, cu șapte mărgele având partea centrală globulară, ornamentată cu cercuri canelate asemănătoare decorului de pe mărgelele de aceeași formă de la Ostrov. Colierul are un pandantiv format dintr-un denar roman din aur cu portretul împăratului Caracalla, emis la Roma în anii 199-200, încadrat de o ramă circulară, torsionată, din aur și se datează la începutul secolului al III-lea p. Chr. ${ }^{28}$

La Muzeul de Istorie Națională și Arheologie Constanța există două coliere cu mărgele din foaie din aur, cu corpul globular şi extremitățile cilindrice, ușor evazate și răsfrânte, ambele descoperite la Mangalia (Callatis), care au bune analogii pentru formă cu cele de la Ostrov. Colierul cu nr. inv. 34665, care datează din secolul al III-lea p. Chr., se compune din 21 de mărgele din foaie de aur intercalate cu 22 de mărgele prismatice din sticlă de culoare albastră și una verde. Celălalt colier (nr. inv. 17887), fragmentar, încadrat cronologic în secolul al IV-lea p. Chr., a fost descoperit în 1968, într-un mormânt cu lespezi din piatră în urma excavațiilor de pe strada Oituz și constă din cinci mărgele, dintre care două mai mici, ovoidale și trei similare celor de la Ostrov ${ }^{29}$.

Un colier compus din 26 de mărgele cu o formă asemănătoare perlelor din foaie din aur de la Ostrov, dar fără decorul median de alveole mărginite de cercuri canelate, se află în colecția Muzeului Național de Istorie a României (nr. inv. 11080). Colierul datează din secolele III-IV p. Chr. și provine, probabil din Dobrogea, însă nu sunt cunoscute condițiile în care a fost descoperit ${ }^{30}$.

\footnotetext{
${ }^{24}$ Ruseva-Slokoska 1991, 125, cat. no. 54 a, tip II, varianta 4.

${ }^{25}$ Popović 1996, 121.

${ }^{26}$ Ruseva-Slokoska 1991, 145, cat. no. 112

${ }^{27}$ Jeremić 2012, 86,87, cat. 51, 52, 53.

${ }^{28}$ Popović 1996, 186, cat. 118 .

${ }^{29}$ Lungu, Covacef, Chera 2012, 118, pl. LV, 25 și pl. LVII, 26.

${ }^{30}$ Oanță-Marghitu 2014, 451, cat. 103.
} 
Mărgelele de la Ostrov sunt un exemplu de artefact local de bună calitate, lucrate într-o tehnică remarcabilă, a căror formă reflectă o puternică influență elenistică, fiind probabil un produs al unor meșteri aurari emigranți din răsărit sau autohtoni, dar care au lucrat și pentru veterani veniți din provinciile estice ale Imperiului roman și stabiliți la Durostorum.

Din sumarul podoabelor predate autorităților în anul 1949 de către cei trei țărani din comuna Ostrov se mai păstrează și 34 de elemente de podoabe disparate: 18 aplice în formă de casete din foaie de aur având încastrate pietre semiprețioase și pastă de sticlă, 15 foi subțiri din aur și un buton.

Două dintre aplice sunt casete cordiforme, din foaie din aur, în care au fost încastrate câte două granate caboșon, separate de o bandă mediană, longitudinală, din foaie de aur. La ambele aplice s-au păstrat numai pietrele din despărțitura din partea stângă. Pe spate sunt lipite două anouri mici, din fir subțire de aur, pentru fixare. La una dintre piese (nr. inv. 9442), veriga de la extremitatea ascuțită nu se mai păstrează, fiind smulsă cu tot cu o bucată de material, de formă cvasitriunghiulară, din vârful foii de aur, care constituia baza casetei (inv. 9441-9442).

Dintre cele douăsprezece casete din foaie de aur în formă de lacrimă, șapte au încastrate câte un granat caboșon în formă de picătură, iar din cinci lipsesc pietrele. Pe spatele casetelor sunt lipite două anouri pentru prindere, foarte mici, din sârmă subțire de aur (nr. inv. 9443-9454).

Patru aplice sunt în formă de casete romboidale, cu bazele și laturile din foaie subțire din aur. În două dintre ele se mai păstrează o pastă de sticlă de culoare verde. Din celelalte două pasta de sticlă lipsește. Pe foile din aur rombice, care constituie bazele casetelor, sunt lipite două verigi, pentru fixare, din fir subțire de aur (nr. inv. 9455-9458).

Se mai păstrează cincisprezece foi subțiri din aur, dintre care șapte sunt decupate în formă de romb, trei sunt în formă de picătură, iar cinci sunt fragmentare și deformate (nr. inv. 9464-9479).

O aplică în formă de disc convex, mic, din foaie din aur, prevăzut în interior cu o mică toartă pentru prindere, din sârmă foarte subțire de aur, completează inventarul păstrat din descoperirea de la Ostrov (inv. 9480).

Fiind elemente de podoabe disparate, în absența unui context arheologic şi în lipsa altor mărturii, este dificil de precizat funcționalitatea acestor aplice, care fac parte din ansamblul de obiecte preluat sau confiscat de la cei trei ostroveni cu aproape 70 de ani în urmă.

Aplicele de la Ostrov se încadrează în tendința dominantă a stilului podoabelor romane din secolele II-IV p. Chr., care este policromia, realizată prin folosirea cu preeminență a pietrelor semiprețioase și a pastei de sticlă în culori variate, încastrate în casete din foaie de aur de diferite forme. Tehnica ornamentării policrome, de influență est-mediteraneeană, folosită în mod curent la cercei (inaures) și la colierele de tip hormoi, a apărut ca proiectare a intenţiei meșterilor romani de a imita podoabele elenistice, ca reflectare a dorinței acestora de a le conferi o aparență de lux obținând totodată rezultatul vizual scontat. Uneori efectul coloristic nu era realizat prin încastrarea pietrelor prețioase ori semiprețioase, ci folosind pasta de sticlă, material mai ieftin și o metodă tehnică mai simplă ${ }^{31}$. Exemplu relevant în acest sens sunt cele patru casete romboidale, din foaie din aur, de la Ostrov, în două dintre ele păstrându-se încă o pastă de sticlă verde, care imită smaraldul. Începând cu secolul al III-lea p. Chr. efectele coloristice la podoabele romane au devenit remarcabile și generalizate, acestea fiind de o bogăție extravagantă, dar adesea deluzorie, căci pasta de sticlă înlocuia frecvent pietrele veritabile ${ }^{32}$.

La British Museum există un colier, încadrat cronologic în secolele I-III p. Chr., care se compune din 22 de granate încastrate în casete rombice, din foaie din aur similare casetelor romboidale de la Ostrov ${ }^{33}$.

Analogii bune pentru configurația cordiformă și tehnica încastrării pietrelor semiprețioase în casete din foaie de aur se întâlnesc la o pereche de cercei cu terminațiile decorate cu un granat în formă de inimă, care provine dintr-un mormânt de la Tortosa, din Siria şi datează din secolul al II-lea p. Chr. și la un cercel cu un sardonix cordiform datat tot în secolul al II-lea p. Chr., descoperit la Vulci, în Italia ${ }^{34}$. O altă pereche de cercei, tot de la British Museum, cu trei pandantive în formă de picătură,

\footnotetext{
${ }^{31}$ Popović 2010, 61.

${ }^{32}$ Coche de la Ferté 1956, 94.

${ }^{33}$ Marshall 1911, 312, pl. LVI, cat. 2700.

${ }^{34}$ Marshall 1911, 279-280, pl. LI, cat. 2370, 2371, 275, pl. LI, cat. 2338.
} 
asemănătoare casetelor din foaie de aur, cu granate caboșon în formă de lacrimă de la Ostrov, a fost datată în secolul al III-lea p. $\mathrm{Chr}^{35}$.

Granate șlefuite caboșon în formă de picătură, încastrate în casete din foaie din aur, sunt montate și pe plăcile unor cercei asamblați din mai multe elemente, de la Muzeul de Istorie Națională și Arheologie Constanța (MINAC., nr. inv 34940, 34941). Tot pe plăcile cerceilor mai sunt fixate o casetă ovală cu un granat caboșon și două casete pătrate cu pastă de sticlă verde, care încadrează o casetă ovală cu un cuarț fumuriu caboșon ${ }^{36}$. Perechea de cercei face parte din inventarul bogat al mormântului unei femei, descoperit la Constanța, în anul 1986, cu ocazia excavațiilor de la fundația unor blocuri de locuințe de pe Bulevardul Ferdinand. Tot în mormântul M1 au mai fost descoperite opt casete disparate din foaie din aur - două rectangulare, umplute cu pastă de sticlă verde (MINAC. inv. 34922, 34923), două ovale și patru rotunde având încastrat câte un granat caboșon (MINAC. nr. inv. 34933-34938), care împreună cu un element central, din foaie de aur, având o casetă ovală cu un granat caboșon la mijloc (M.I.N.A.C. nr. inv. 34942), sunt considerate a fi elemente de la o diademă ${ }^{37}$.

La Museo Nazionale Romano din Roma există un colier cu 23 de elemente formate din casete din foaie din aur cu granate caboşon în formă de picătură, foarte bine păstrat, descoperit la Mentana și care datează din secolul I p. Chr. ${ }^{38}$ Granatele tăiate caboșon, încastrate în casete în formă de lacrimă, sunt foarte asemănătoare celor din inventarul sarcofagului de la Ostrov, cu deosebirea că anourile pentru fixare sunt lipite de ramele casetelor și nu pe spatele foilor de la bazele acestora. Un colier, care se încadrează în același tip și este datat la începutul secolului al III-lea p. Chr., se află la Musée de la Civilisation Gallo-Romaine din Lyon. Colierul de la Lyon are elementele formate din casete rotunde, în care sunt montate granate șlefuite caboșon, de care sunt suspendate pandantive în formă de casete din foaie de aur, cu granate având configurația de lacrimă, care prezintă bune analogii pentru aplicele de la Ostrov $^{39}$.

În colecţia Muzeului Național din Belgrad există o aplică disparată, în formă de casetă rectangulară din foaie din aur, din care lipsește piatra sau pasta de sticlă, cu anouri pentru fixare dispuse pe fiecare dintre cele patru laturi, ceea ce sugerează faptul că făcea parte dintr-un colier. Luând în considerare o piesă similară descoperită la Kostolac (Viminacium) conchidem că astfel de elemente de podoabe erau în uz și în timpul Tetrarhiei, confecționarea lor în secolul al IV-lea p. Chr. fiind confirmată și de o descoperire de lângă Leskovac, în Serbia ${ }^{40}$. Între podoabele ce compun inventarul fastuos descoperit în timpul săpăturilor arheologice din anul 1996, în cripta de la mausoleul de la Šarkamen, din estul Serbiei, despre care se presupune că ar fi aparținut mamei împăratului Maximinus Daia (308-313 p. Chr.), se numără și o casetă rectangulară, probabil un pandantiv de colier, din foaie de aur, umplută cu pastă de sticlă și mărginită de un fir perlat ${ }^{41}$.

Utilizate frecvent în secolul al III-lea p. Chr., astfel de elemente de podoabe sub formă de casete din foaie de aur, având încastrate pietre semiprețioase ori pastă de sticlă, fie că erau elemente de colier, fie terminații sau pandantive de cercei, au fost larg răspândite atât în Moesia Superior, cât și în Moesia Inferior în secolele II-IV p. Chr.

Luând în considerare dimensiunile și conturul foilor subțiri din aur, foarte apropiate de configurația foilor de la bazele aplicelor romboidale, celor în formă de picătură, sau cordiforme (unul dintre fragmente pare a fi o jumătate tăiată din foaia de la baza unei casete cordiforme), putem presupune că acestea provin de la casete din care au fost scoase pietrele sau pasta de sticlă, iar ramele din bandă de aur au fost dezlipite. Indicii rezonabile care să conducă la această ipoteză sunt marginile neregulate ale foilor, precum și marginile rupte ale ramelor, unele desprinse, îndoite și pliate, altele fisurate, de la un număr de casete în care pietrele s-au păstrat ori au fost scoase și remontate într-o manieră rudimentară.

Fragmentele de forme nedefinite provin, probabil de la foile din aur de la bazele casetelor din care au fost decupate ulterior porțiuni de material.

\footnotetext{
${ }^{35}$ Marshall 1911, 307, pl. LV, cat. 2668-2669.

${ }^{36}$ Covacef 1994, 185, fig. 63.2; Covacef 2014, 431, fig. 99.1.2.

${ }^{37}$ Covacef 1994, 184, fig. 63.8, 186, 63.7, fig. 63.9; Covacef 2014, 430, fig. 99.1.1.

${ }^{38}$ Pirzio Biroli Stefanelli, 1992, 28, fig. 23-25, 29, cat. 22

${ }^{39}$ Pirzio Biroli Stefanelli, 1992, 192, fig. 229.

${ }^{40}$ Popović $1996,136,190$, cat. 138 , fig. $4 \mathrm{~V}$, tip V, varianta $1 / 3$.

${ }^{41}$ Popović 2010, 61 .
} 
Analizele $^{42}$ cu spectrometrul de fluorescență de raze X efectuate în Secția de Investigații Fizico-Chimice și Biologice a Muzeului Național de Istorie a României asupra foilor și fragmentelor din aur de la Ostrov au relevat faptul că acestea au fost decupate din două foi mai mari de aur. Piesele cu nr. inv. 9464-9469 și 9472-9478 au un procentaj de aur în aliaj cuprins între 89,93\%-90,68\% și au fost decupate dintr-o foaie, iar cele cu nr. inv. 9470 și 9471 conțin aur în proporție de 87,55\%, respectiv $88,37 \%$, fiind decupate din altă foaie de aur. În acest sens investigațiile sunt edificatoare numai pentru foile din aur și casetele goale. În privința casetelor în care s-au păstrat granatele ori pasta de sticlă, rezultatul examinării elementelor componente ale aliajului de aur nu este concludent sub acest aspect, datele reieșite în urma analizei elementelor fiind influențate de prezența celorlalte materiale încastrate (granate, pastă de sticlă).

\begin{tabular}{|c|c|c|c|c|c|c|c|c|c|c|}
\hline Inv. nr. /Denumire ${ }^{43}$ & Mn & $\mathbf{F e}$ & $\mathbf{N i}$ & $\mathbf{C u}$ & $\mathbf{Z n}$ & $\mathbf{Z r}$ & Ag & Sb & Au & $\mathbf{P b}$ \\
\hline 9464 foaie & & 0.06 & 0.001 & 0.001 & & & 9.51 & & 90.43 & \\
\hline 9465 foaie & & 0.13 & 0.05 & 0.001 & & & 9.33 & & 90.50 & \\
\hline 9466 foaie & & 0.10 & 0.001 & 0.001 & & & 9.22 & & 90.68 & \\
\hline 9467 foaie & & 0.08 & 0.04 & 0.001 & & & 9.71 & & 90.17 & \\
\hline 9468 foaie & & 0.09 & 0.05 & 0.001 & & & 9.62 & & 90.11 & 0.14 \\
\hline 9469 foaie & & 0.11 & 0.001 & 0.001 & & & 9.61 & & 90.20 & 0.08 \\
\hline 9470 foaie & & 0.07 & 0.001 & 2.68 & 0.32 & & 9.29 & & 87.55 & 0.1 \\
\hline 9471 foaie & & 0.07 & 0.001 & 2.23 & & & 9.21 & & 88.37 & 0.13 \\
\hline 9472 foaie & & 0.19 & 0.05 & 0.001 & & & 9.59 & & 90.08 & 0.09 \\
\hline 9473 foaie & & 0.10 & 0.05 & 0.001 & 0.34 & & 9.48 & & 89.93 & 0.09 \\
\hline 9474 foaie & & 0.11 & 0.04 & 0.001 & & & 9.43 & & 90.34 & 0.08 \\
\hline 9475 foaie & & 0.16 & 0.05 & 0.001 & 0.29 & & 9.43 & & 90.07 & \\
\hline 9476 foaie & & 0.10 & 0.05 & 0.001 & 0.29 & & 9.28 & & 90.28 & \\
\hline 9477 foaie & & 0.09 & 0.04 & 0.001 & & & 9.59 & & 90.10 & 0.19 \\
\hline 9478 foaie & & 0.11 & 0.04 & 0.001 & & & 9.52 & & 90.06 & 0.27 \\
\hline 9479 buton & & 0.19 & 0.001 & 0.001 & & & 8.81 & & 91.00 & \\
\hline 9440 fibulă - arc & & 0.08 & 0.001 & 0.51 & & & 19.97 & & 79.44 & \\
\hline 9440 fibulă - braț ${ }^{44}$ & & 0.37 & 0.08 & 25.82 & 2.97 & & 15.06 & & 55.62 & 0.09 \\
\hline 9438 cercel - placă & & 0.27 & 0.001 & 0.001 & & & 10.94 & & 88.79 & \\
\hline 9438 cercel - toartă & & 0.28 & 0.001 & 0.001 & & & 11.75 & & 87.98 & \\
\hline 9439 cercel - placă & & 0.28 & 0.06 & 0.001 & & & 10.83 & & 88.83 & \\
\hline 9439 cercel - toartă & & 0 & 0.001 & 0.001 & & & 11.37 & & 88.63 & \\
\hline 9459-9463 șir de mărgele & & 0.10 & 0.001 & 0.001 & & & 4.94 & & 94.96 & \\
\hline 9459-9463 șir de mărgele & & 0.18 & 0.001 & 0.001 & & & 4.99 & & 94.84 & \\
\hline 9442 - aplică & & 0.12 & 0.09 & 3.03 & 0.45 & & 10.10 & & 86.20 & \\
\hline 9441 - aplică & & 0.14 & 0.06 & 2.35 & 0.43 & & 8.85 & & 88.17 & \\
\hline 9443 - aplică & & 0.25 & 0.001 & 3.13 & 2.06 & & 9.41 & & 85.15 & \\
\hline 9448 - aplică & 0.63 & 15 & 0.001 & 2.29 & & & 7.15 & & 74.95 & \\
\hline 9445 - aplică & 0.67 & 20.40 & 0.001 & 0.001 & & 0.02 & 6.27 & & 72.64 & \\
\hline 9446 - aplică & 0.77 & 12.5 & 0.001 & 0.001 & 0.35 & & 7.27 & & 79.12 & \\
\hline 9444 - aplică & & 0 & 0.001 & 0.001 & & & 8.69 & & 91.31 & \\
\hline 9449 - aplică & & 0.12 & 0.001 & 2.27 & 0.75 & & 8.92 & & 87.94 & \\
\hline 9450 - aplică & & 0.08 & 0.001 & 0.001 & & & 9.02 & & 90.91 & \\
\hline 9451 - aplică & & 0.20 & 0.001 & 0.001 & & & 7.88 & & 91.92 & \\
\hline 9452 - aplică & & 0.29 & 0.05 & 0.001 & 0.36 & & 9.55 & & 89.74 & \\
\hline 9453 - aplică & & 0.31 & 0.05 & 3.31 & 0.33 & & 8.78 & & 87.22 & \\
\hline 9454 - aplică & & 0.58 & 0.001 & 3.09 & 0.34 & & 9.45 & & 86.44 & 0.12 \\
\hline 9455 - aplică & 0.52 & 0.94 & 0.001 & 3.07 & & 0.06 & 8.29 & 0.83 & 81.96 & 4.32 \\
\hline 9456 - aplică & & 0.15 & 0.001 & 0.001 & 0.58 & & 8.68 & & 90.59 & \\
\hline 9457 - aplică & & 0.15 & 0.001 & 0.001 & & & 8.27 & & 91.45 & 0.14 \\
\hline 9458 - aplică & & 0.15 & 0.001 & 0.001 & & & 8.34 & & 91.50 & \\
\hline
\end{tabular}

${ }^{42}$ Analizele au fost realizate de doamna dr. Migdonia Georgescu, șef secție de Investigații Fizico-Chimice și Biologice a MNIR.

${ }^{43}$ Analizele au fost efectuate cu un spectrometru portabil de fluorescență de raze X dotat cu anticatod din W, dioda SiPIN. Parametri de lucru: tensiune $35 \mathrm{kV}$, intensitate 35 microA, timp de achiziţie $120 \mathrm{~s}$.

${ }^{44}$ Coroziune din miez. 

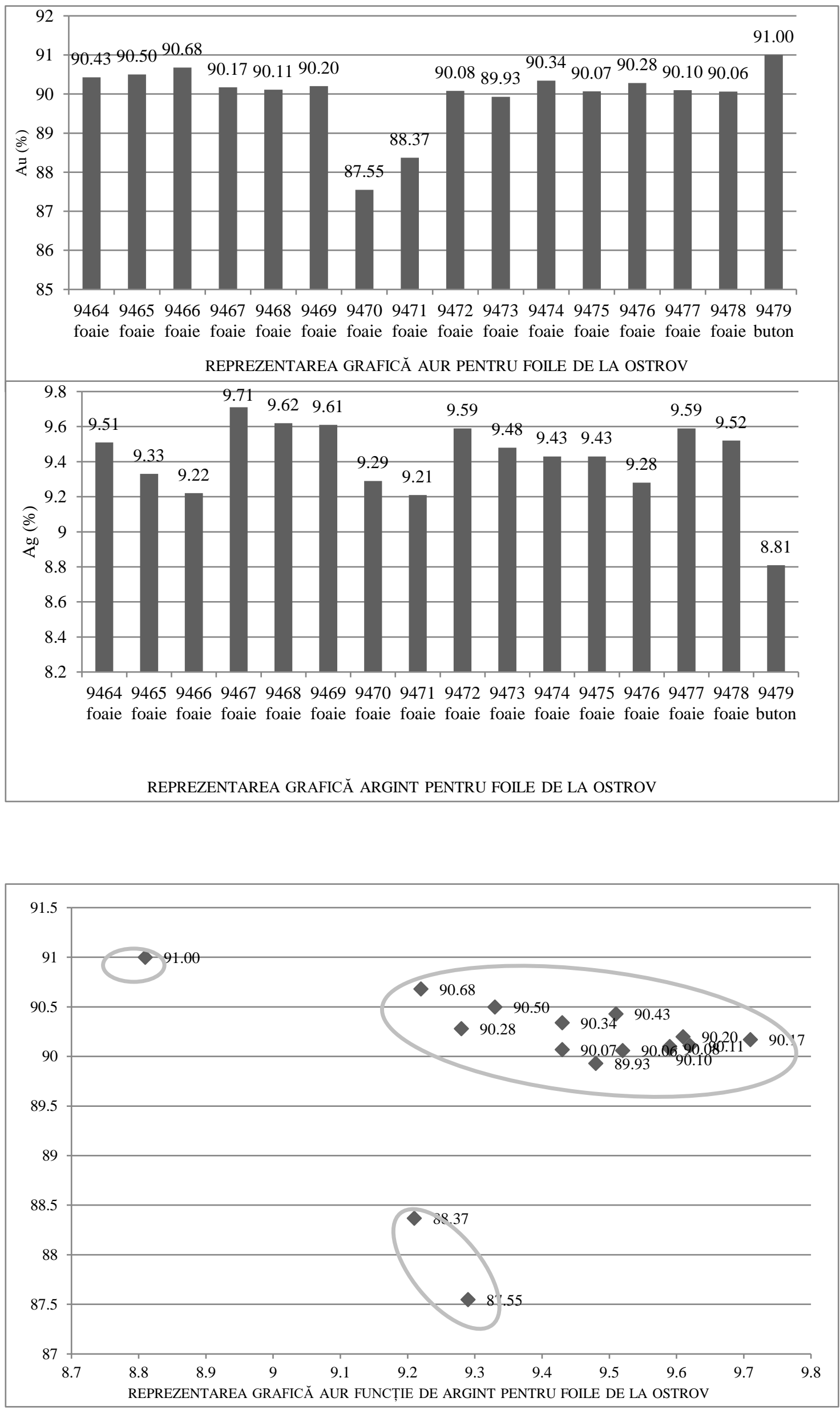


\begin{tabular}{|l|l|l|l|l|l|l|l|l|l|l|l|l|l|l|l|}
\hline \multicolumn{10}{|c|}{ Analiza chimică a piesei nr. inv. 9455 aplică - av (sticlă verde $)^{45}$} \\
\hline S & $\mathrm{Cl}$ & $\mathrm{K}$ & $\mathrm{Ca}$ & $\mathrm{Ti}$ & $\mathrm{Mn}$ & $\mathrm{Fe}$ & $\mathrm{Cu}$ & $\mathrm{Zn}$ & $\mathrm{Sr}$ & $\mathrm{Zr}$ & $\mathrm{Ag}$ & $\mathrm{Sn}$ & $\mathrm{Sb}$ & $\mathrm{Au}$ & $\mathrm{Pb}$ \\
\hline 897 & 657 & 18836 & 51441 & 825 & 6240 & 9531 & 15058 & 414 & 853 & 89 & 312 & 1671 & 4322 & 1641 & 12763 \\
\hline
\end{tabular}

Conchidem că există argumente suficiente să considerăm că aplicele în formă de casete cu granate caboșon sau pastă de sticlă verde, precum și foile din aur, rombice sau în formă de lacrimă, care provin de la casete deteriorate, constituiau împreună, elementele componente ale aceluiaşi obiect de podoabă. Având în vedere cvasiparitatea între elementele în formă de picătură și cele rombice am putea presupune că formau inițial un colier de tip hormoi, casetele în formă de lacrimă alternând cu cele romboidale, extremităţile fiind încheiate de aplicele cordiforme. Acestei supoziții i se poate aduce obiecția că amplasarea anourilor pentru prindere pe spatele casetelor şi nu pe laturile acestora este nefirească. Precizarea funcționalităţii acestor elemente de podoabă disparate este cu atât mai dificilă în condițiile în care contextul descoperirii de la Ostrov este necunoscut.

\section{CONCLUZII}

Artefactele de la Ostrov fac, probabil, parte din inventarul sarcofagului unui personaj cu rang militar sau administrativ înalt, care provenea dintr-una din familiile nobile (illustres), care ocupau poziții sociale importante în Durostorum, în a doua jumătate a secolului al III-lea și la începutul secolului al IV-lea p. Chr. Argumentul care pledează în favoarea acestei supoziții ar fi prezența în setul de podoabe găsit de cei trei ostroveni a fibulei cruciforme din aur, atribut al conducătorilor sau ofițerilor superiori romani. Existența cerceilor și a mărgelelor, podoabe specific feminine, ar face plauzibilă prezumția că în sarcofag au fost depuse două schelete. Informațiile cu privire la condițiile descoperirii de la Ostrov fiind vagi, putem doar presupune, fără a avea certitudinea, că al doilea schelet ar fi fost al soției defunctului.

Obiectele de podoabă descoperite de cei trei țărani din comuna Ostrov, asemeni podoabelor și obiectelor ornamentale din aur, provenite din alte morminte din necropolele de la Durostorum, își găsesc analogii în piese contemporane lor, care provin din siturile de la Viminacium, Ratiaria, Novae, Sexaginta Prista și Augusta Traiana. Aceasta, precum și premisa că piesele au fost executate cu câteva decenii înainte de a fi depuse în morminte, constituie argumente pentru concluzia că pe lângă castrele romane din Moesia Superior și Moesia Inferior au funcționat ateliere locale, în care meșteri aurari autohtoni sau emigranți din provinciile estice ale imperiului, produceau podoabe din aur încă din secolul al II-lea p. Chr. continuându-și activitatea și în secolele al III-lea și al IV-lea p. Chr. ${ }^{46}$

$\mathrm{Cu}$ privire la proveniența aurului din care au fost realizate artefactele produse în atelierele locale de la Durostorum, este de luat în considerare argumentaţia lui Bogdan Dimitrov Filov care, întro lucrare despre tezaurul descoperit la Nikolaevo, presupune că în atelierele de orfevrărie din nordul Bulgariei, în secolele II-III p. Chr., era prelucrat cu precădere aurul extras din minele exploatate de romani din Dacia sau din Dalmaţia ${ }^{47}$.

Tezaurul de la Ostrov este un ansamblu eterogen de obiecte de podoabă și consistă din piese produse în mai multe ateliere, unele probabil locale şi care datează din perioade de timp diferite, cuprinse între prima jumătate sau mijlocul secolului al III-lea p. Chr. și începutul secolului al IV-lea p. Chr.

În mod cert, setul de obiecte de podoabă din aur de la Ostrov era mai bogat. Din nefericire, așa cum se întâmplă în cazul celor mai multe descoperiri incidentale, și de această dată, cei care au găsit piesele, fie din ignoranță, fie din dorința de a obține un profit, chiar dacă mult sub valoarea descoperirii, pesemne au înstrăinat mai multe artefacte și au deteriorat grav o mare parte dintre cele rămase, care au fost recuperate de autorități.

\footnotetext{
${ }^{45}$ Analizele au fost efectuate cu un spectrometru portabil de fluorescență de raze X dotat cu anticatod din W, dioda SiPIN. Parametri de lucru: tensiune $30 \mathrm{kV}$, intensitate 35 microA (pentru elementele grele); tensiune $15 \mathrm{kV}$, intensitate 6 microA (pentru elementele ușoare); timp de achiziție $60 \mathrm{~s}$.

${ }^{46}$ Donevski 1999, 70-71.

47 Филов 1915, 48.
} 


\section{CATALOG $^{48}$}

1. CERCEL. Aur, turnare, batere, trefilare, lipire. $\mathrm{D}=$ $1,40 \mathrm{~cm}, \mathrm{I}=2,70 \mathrm{~cm}, \mathrm{G}=2,77 \mathrm{~g}$. MNIR inv. nr. 9438. În formă de rozetă cu șase petale cu toarta în forma literei „S”.

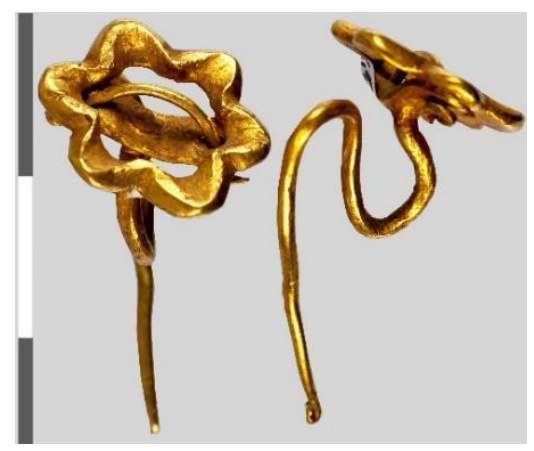

2. CERCEL. Aur, turnare, batere, trefilare, lipire. $\mathrm{D}=$ $1,40 \mathrm{~cm}, \mathrm{I}=2,70 \mathrm{~cm}, \mathrm{G}=2,69 \mathrm{~g}$. MNIR inv. $\mathrm{nr}$. 9439. În formă de rozetă cu șase petale cu toarta în forma literei „,S”.

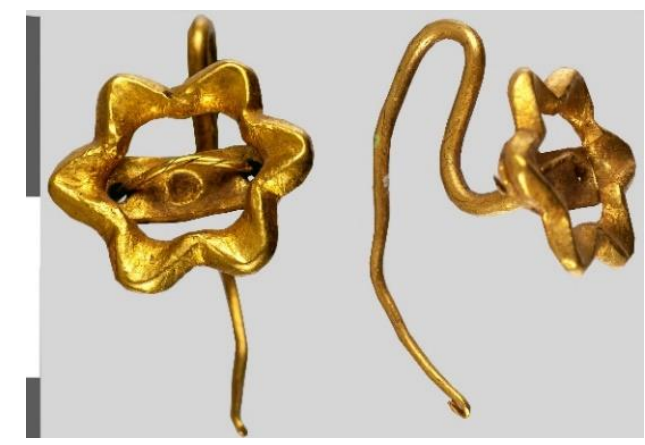

3. FiBULĂ. Aur, cupru, turnare, batere, lipire, incizare, nielare. $\mathrm{L}=4,68 \mathrm{~cm}, \mathrm{LA}=3,70 \mathrm{~cm}, \mathrm{I}=2,10 \mathrm{~cm}, \mathrm{G}=$ 9,64 g. MNIR inv. nr. 9440. Cruciformă, cu ax transversal de secțiune rectangulară, din cupru, acoperit cu foaie din aur, cu butoni sferici la capete. Între butoni, o placă semicirculară din aur, bordată cu linii incizate. Arc din bandă groasă din aur, curbată, cu decor incizat incrustat cu niello. Picior în formă de prismă semicirculară din foaie de aur cu deschizătură laterală pentru ac. Acul nu se mai păstrează.

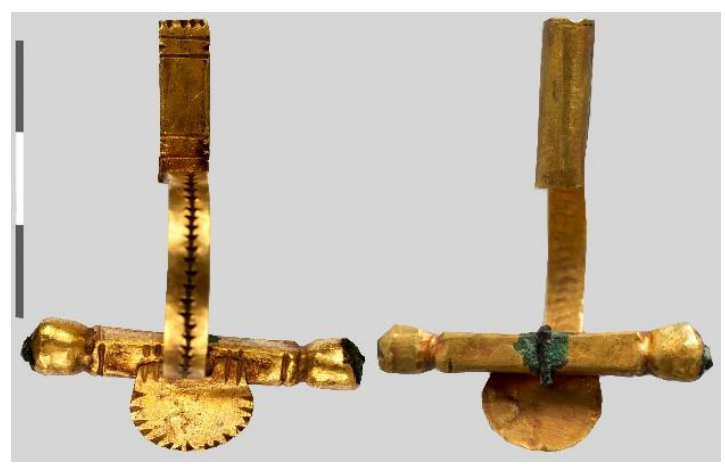

\footnotetext{
${ }^{48}$ Abrevieri folosite în catalog: $\mathrm{D}=$ diametru, $\mathrm{G}=$
} greutate, $\mathrm{L}=$ lungime, $\mathrm{LA}=$ lățime.
4. MǍrgeA. Aur, batere. $\mathrm{L}=0,85 \mathrm{~cm}, \mathrm{LA}=0,34 \mathrm{~cm}$, $\mathrm{G}=0,11 \mathrm{~g}$. MNIR inv. nr. 9459. Tubulară, în formă de amforetă, cu partea centrală globulară, ornamentată cu patru alveole concave mărginite de cercuri canelate. Terminațiile cilindrice, evazate progresiv și răsfrânte spre exterior.

5. MĂRGEA. Aur, batere. $\mathrm{L}=0,81 \mathrm{~cm}, \mathrm{LA}=0,34 \mathrm{~cm}$, $\mathrm{G}=0,10 \mathrm{~g}$. MNIR inv. nr. 9460. Tubulară, în formă de amforetă, cu partea centrală globulară, ornamentată cu patru alveole concave mărginite de cercuri canelate. Terminațiile cilindrice, evazate progresiv și răsfrânte spre exterior.

6. MĂRGEA. Aur, batere. $\mathrm{L}=0,81 \mathrm{~cm}, \mathrm{LA}=0,44 \mathrm{~cm}$, $\mathrm{G}=0,10 \mathrm{~g}$. MNIR inv. nr. 9461. Tubulară, în formă de amforetă, cu partea centrală globulară, ornamentată cu patru alveole concave mărginite de cercuri canelate. Terminațiile cilindrice, evazate progresiv și răsfrânte spre exterior.

7. MĂRGEA. Aur, batere. $\mathrm{L}=0,77 \mathrm{~cm}, \mathrm{LA}=0,38 \mathrm{~cm}$, $\mathrm{G}=0,07 \mathrm{~g}$. MNIR inv. nr. 9462. Tubulară, în formă de amforetă, cu partea centrală globulară, ornamentată cu patru alveole concave mărginite de cercuri canelate. Terminațiile cilindrice, evazate progresiv și răsfrânte spre exterior.

8. MĂRGEA. Aur, batere. $L=0,75 \mathrm{~cm}, L A=0,42 \mathrm{~cm}$, $\mathrm{G}=0,07 \mathrm{~g}$. MNIR inv. nr. 9463. Tubulară, în formă de amforetă, cu partea centrală globulară, ornamentată cu patru alveole concave mărginite de cercuri canelate. Terminațiile cilindrice, evazate progresiv și răsfrânte spre exterior.

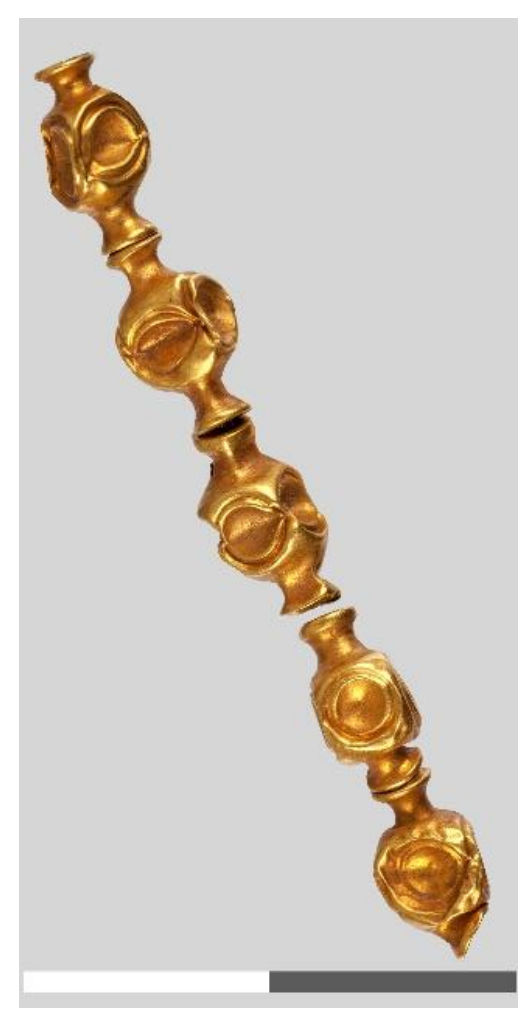


9. APLICÁ. Aur, granat, batere, lipire. $\mathrm{L}=1,25 \mathrm{~cm}$, $\mathrm{LA}=1,12 \mathrm{~cm}, \mathrm{G}=0,77 \mathrm{~g}$. MNIR inv. nr. 9441 . Casetă cordiformă, din foaie de aur, cu un granat caboșon. Pe spate două anouri pentru prindere. Lipsește piatra din despărțitura din partea dreaptă.

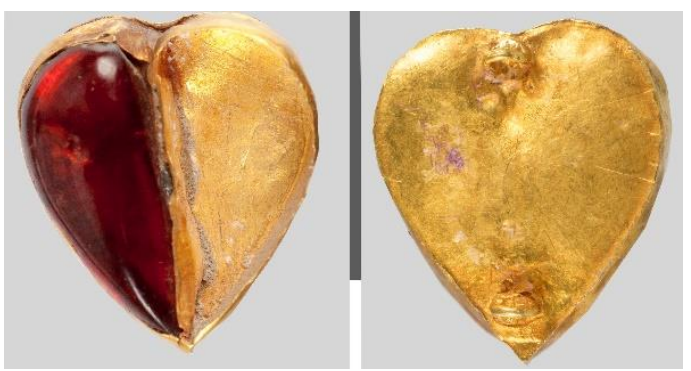

10. APLICĂ. Aur, granat, batere, lipire. $\mathrm{L}=1,27 \mathrm{~cm}$, $\mathrm{LA}=1,15 \mathrm{~mm} ., \mathrm{G}=0,79 \mathrm{~g}$. MNIR inv. nr. 9442 . Casetă cordiformă, din foaie de aur cu un granat caboșon. Pe spate un anou pentru prindere, celălalt a fost smuls cu tot cu o parte din vârful foii de aur de la baza casetei. Lipsește piatra din despărțitura din partea dreaptă.

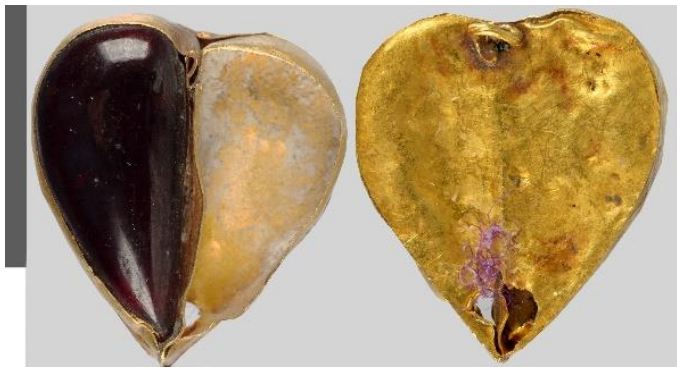

11. APLICĂ. Aur, batere, lipire. $L=1,13 \mathrm{~cm}, \mathrm{LA}=$ $0,64 \mathrm{~cm}, \mathrm{G}=0,23 \mathrm{~g}$. MNIR inv. nr. 9450 . Casetă din foaie din aur în formă de ,picătură”. Pe spate două anouri pentru prindere. Rama, din foaie de aur, îndoită. Lipsește piatra.

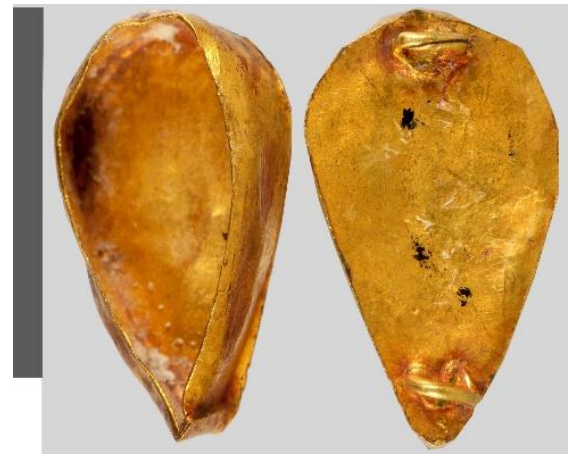

12. APLICĂ. Aur, batere, lipire. $L=1,08 \mathrm{~cm}, \mathrm{LA}=$ $0,54 \mathrm{~cm}, \mathrm{G}=0,22 \mathrm{~g}$. MNIR inv. nr. 9451. Casetă din foaie din aur în formă de ,,picătură”. Pe spate două anouri pentru fixare. Rama, din foaie din aur, deformată și îndoită. Lipsește piatra.

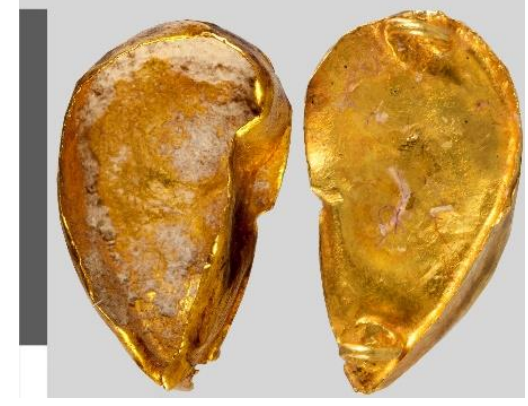

13. APLICĂ. Aur, batere, lipire. $\mathrm{L}=1,12 \mathrm{~cm}, \mathrm{LA}=$ $0,63 \mathrm{~cm}, \mathrm{G}=0,22 \mathrm{~g}$. MNIR inv. nr. 9452. Casetă din foaie din aur în formă de ,picătură”. Pe spate două anouri pentru prindere. Rama, din foaie din aur, îndoită spre exterior. Lipsește piatra.

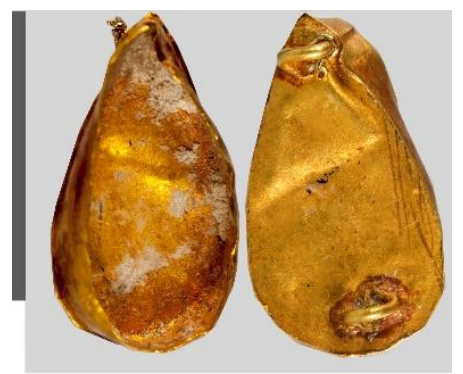

14. APLICĂ. Aur, batere, lipire. $\mathrm{L}=1,13 \mathrm{~cm}, \mathrm{LA}=$ $0,48 \mathrm{~cm}, \mathrm{G}=0,25 \mathrm{~g}$. MNIR inv. nr. 9453. Casetă din foaie din aur în formă de ,picătură”. Pe spate două anouri pentru fixare. Caseta deformată. Rama, din foaie de aur, îndoită spre exterior. Lipsește piatra.

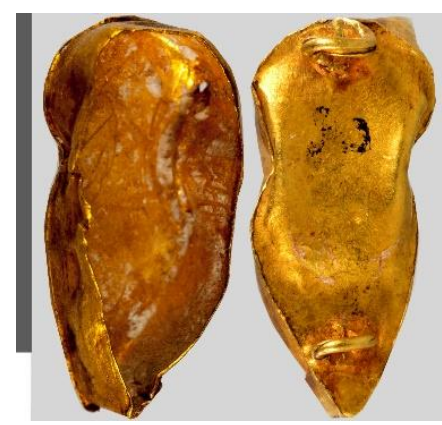

15. APLICĂ. Aur, batere, lipire. $\mathrm{L}=1,05 \mathrm{~cm}, \mathrm{LA}=$ $0,61 \mathrm{~cm}, \mathrm{G}=0,24 \mathrm{~g}$. MNIR inv. nr. 9454. Casetă din foaie din aur în formă de ,picătură”. Pe spate două anouri pentru prindere. Rama, din foaie din aur, ruptă și îndoită spre exterior. Lipsește piatra.

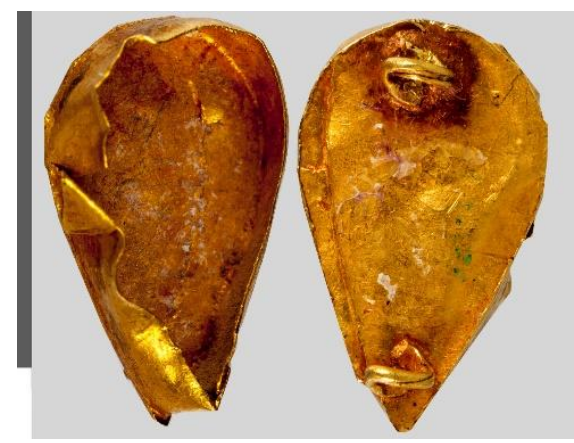


16. APLICĂ. Aur, granat, batere, lipire. $L=1,13 \mathrm{~cm}$, $\mathrm{LA}=0,63 \mathrm{~cm}, \mathrm{G}=0,63 \mathrm{~g}$. MNIR inv. nr. 9443 .

Casetă din foaie de aur cu un granat caboșon în formă de ,picătură”. Pe spate două anouri pentru prindere. Rama, din foaie de aur îndoită.

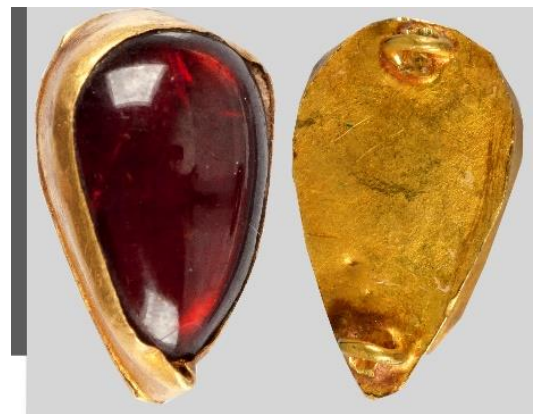

17. APLICĂ. Aur, granat, batere, lipire. $\mathrm{L}=1,09 \mathrm{~cm}$, $\mathrm{LA}=0,63 \mathrm{~cm}, \mathrm{G}=0,56 \mathrm{~g}$. MNIR inv. nr. 9444 . Casetă din foaie de aur cu un granat caboșon în formă de ,picătură”. Pe spate două anouri pentru fixare. Rama, din foaie din aur, îndoită.

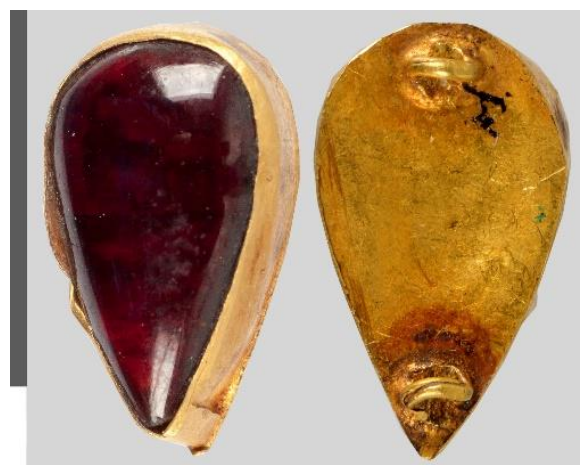

18. APLICĂ.Aur, granat, batere, lipire. $\mathrm{L}=1,11 \mathrm{~cm}$, $\mathrm{LA}=0,64 \mathrm{~cm}, \mathrm{G}=0,66 \mathrm{~g}$. MNIR inv. nr. 9445 . Casetă din foaie de aur cu un granat caboșon în formă de ,picătură”. Pe spate două anouri pentru fixare. Piatra fisurată în zona mediană.

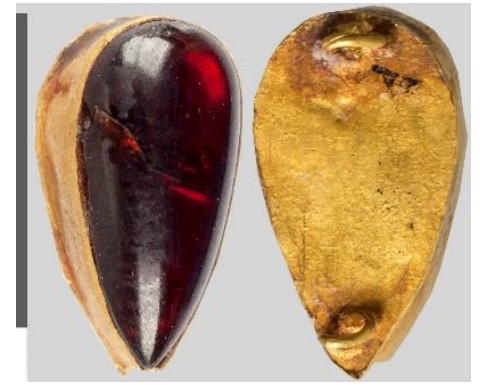

19. Aplică. Aur, granat, batere, lipire. $\mathrm{L}=1,06 \mathrm{~cm}$, $\mathrm{LA}=0,66 \mathrm{~cm}, \mathrm{G}=0,57 \mathrm{~g}$. MNIR inv. nr. 9446. Casetă din foaie de aur cu un granat caboșon în formă de ,picătură”. Pe spate două anouri pentru fixare.

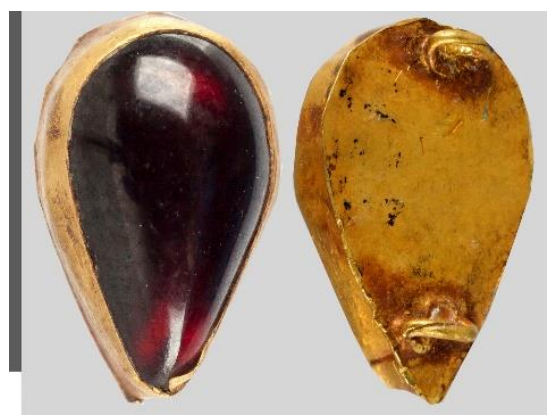

20. APLICĂ. Aur, granat, batere, lipire. $\mathrm{L}=1,10 \mathrm{~cm}$, $\mathrm{LA}=0,66 \mathrm{~cm}, \mathrm{G}=0,48 \mathrm{~g}$. MNIR inv. nr. 9447. Casetă din foaie de aur cu un granat caboșon în formă de ,picătură”. Pe spate două anouri pentru prindere. Rama, din foaie de aur, îndoită şi pliată.

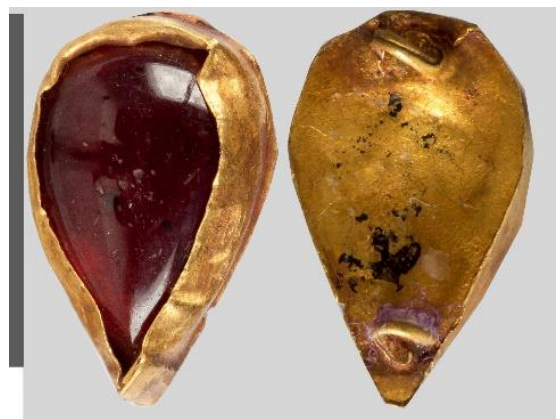

21. APLICĂ. Aur, granat, batere, lipire. $\mathrm{L}=1,06 \mathrm{~cm}$, $\mathrm{LA}=0,66 \mathrm{~cm}, \mathrm{G}=0,47 \mathrm{~g}$. MNIR inv. nr. 9448 . Casetă din foaie de aur cu un granat caboșon în formă de ,picătură”. Pe spate două anouri pentru fixare. Rama, din foaie de aur, îndoită, deformată.

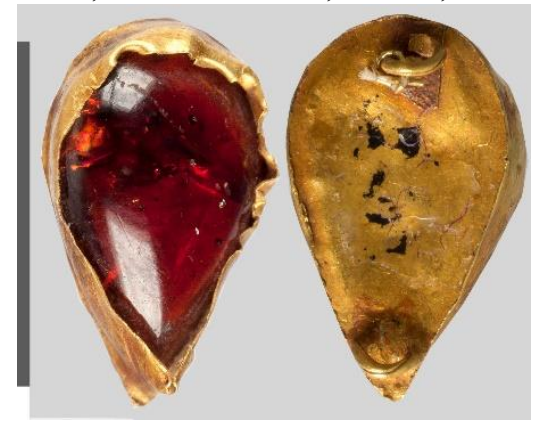

22. Aplică. Aur, granat, batere, lipire. $\mathrm{L}=1,10 \mathrm{~cm}$, $\mathrm{LA}=0,63 \mathrm{~cm}, \mathrm{G}=0,41 \mathrm{~g}$. MNIR inv. nr. 9449 . Casetă din foaie de aur cu un granat caboșon în formă de ,picătură”. Pe spate două anouri pentru fixare. Rama, din foaie de aur, îndoită, deformată.

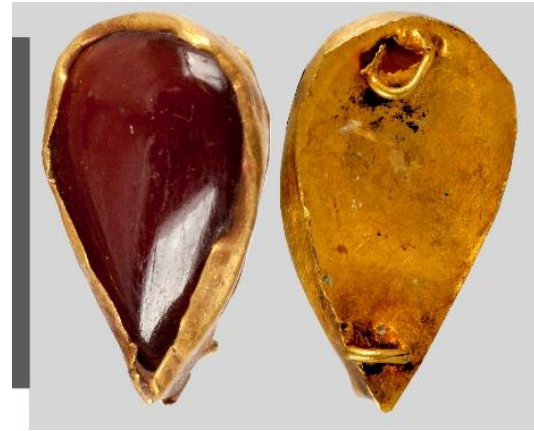


23. APLICĂ. Aur, pastă de sticlă, batere, lipire. $L=$ $1,45 \mathrm{~cm}, \mathrm{LA}=0,93 \mathrm{~cm}, \mathrm{G}=0,83 \mathrm{~g}$. MNIR inv. nr. 9455. Casetă romboidală din foaie de aur cu o pastă de siclă verde. Pe spate două anouri pentru fixare. Marginile ramei, din foaie de aur, îndoite.

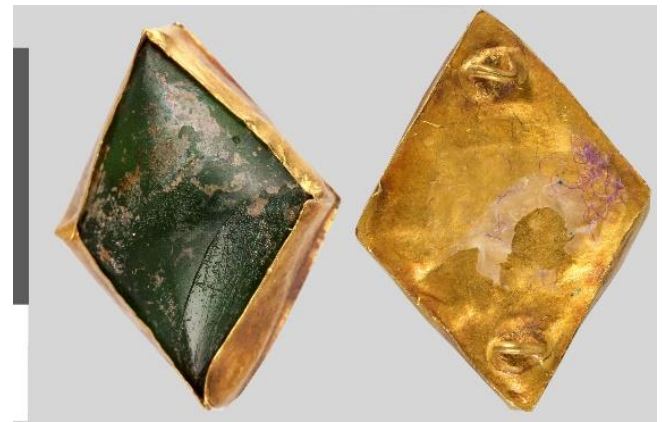

24. APLICĂ. Aur, pastă de sticlă, batere, lipire. $\mathrm{L}=$ $1,50 \mathrm{~cm}, \mathrm{LA}=1,04 \mathrm{~cm}, \mathrm{G}=0,68 \mathrm{~g}$. MNIR inv. nr. 9456. Casetă romboidală din foaie de aur cu o pastă de siclă verde. Pe spate două anouri pentru fixare. Rama, din foaie din aur, ruptă la unul dintre vârvuri, marginile îndoite.

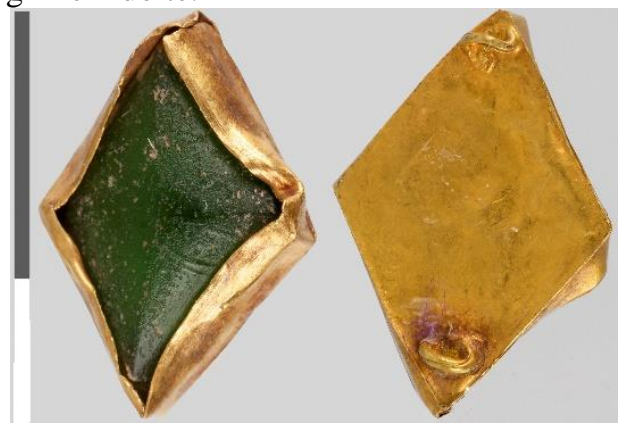

25. APLICĂ. Aur, batere, lipire. $\mathrm{L}=1,52 \mathrm{~cm}, \mathrm{LA}=$ $1,12 \mathrm{~cm}, \mathrm{G}=0,36 \mathrm{~g}$. MNIR inv. nr. 9457. Casetă romboidală din foaie de aur. Marginile ramei, din foaie de aur, rupte și îndoite spre exterior. Pe spate două anouri pentru fixare. Lipsește pasta de sticlă.

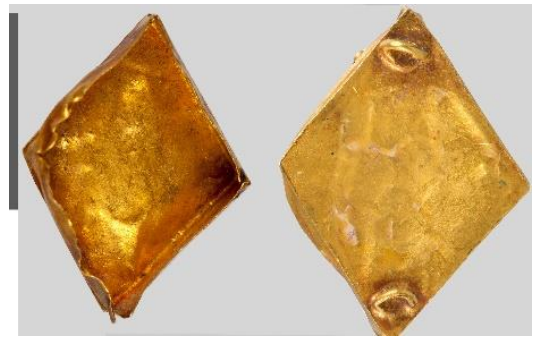

26. A APLICĂ. Aur, batere, lipire. $\mathrm{L}=1,46 \mathrm{~cm}, \mathrm{LA}=$ $1,07 \mathrm{~cm}, \mathrm{G}=0,34 \mathrm{~g}$. MNIR inv. nr. 9458. Casetă romboidală din foaie de aur. Marginile ramei, din foaie de aur, îndoite spre exterior. Pe spate două anouri pentru fixare. Lipsește pasta de sticlă.

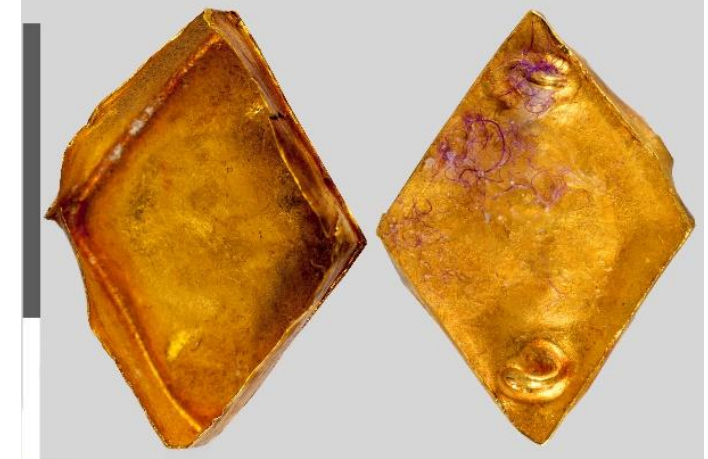

27. FOAIE DIN AUR. Aur, batere. $\mathrm{L}=1,35 \mathrm{~cm}, \mathrm{LA}=$ $1,10 \mathrm{~cm}, \mathrm{G}=0,05 \mathrm{~g}$. MNIR inv. nr. 9464 . Romboidală, cu marginile neregulate, rupte.

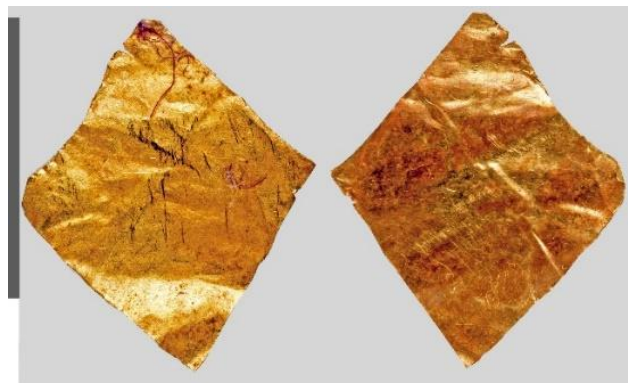

28. FOAIE DIN AUR. Aur, batere. $\mathrm{L}=1,00 \mathrm{~cm}, \mathrm{LA}=$ $0,60 \mathrm{~cm}, \mathrm{G}=0,02 \mathrm{~g}$. MNIR inv. nr. 9465. În formă de ,picătură”, cu vârful îndoit și pliat.

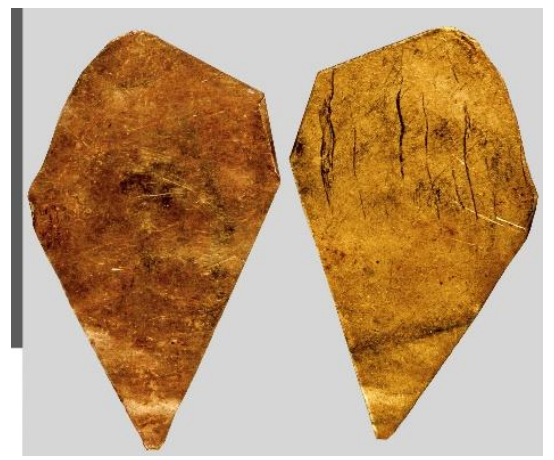

29. Foaie din aur. Aur, batere. $\mathrm{L}=1,05 \mathrm{~cm}, \mathrm{LA}=$ $0,65 \mathrm{~cm}, \mathrm{G}=0,03 \mathrm{~g}$. MNIR inv. nr. 9466 . Romboidală, cu o latură îndoită și pliată.

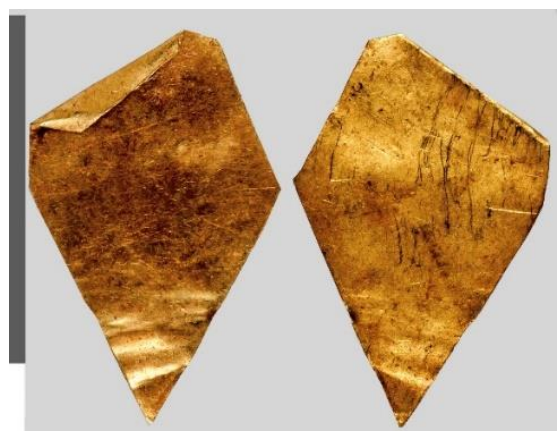


30. Foaie din aur. Aur, batere. $\mathrm{L}=1,05 \mathrm{~cm}, \mathrm{LA}=$ $0,90 \mathrm{~cm}, \mathrm{G}=0,04 \mathrm{~g}$. MNIR inv. nr. 9467. De formă nedefinită, cu marginile neregulate.

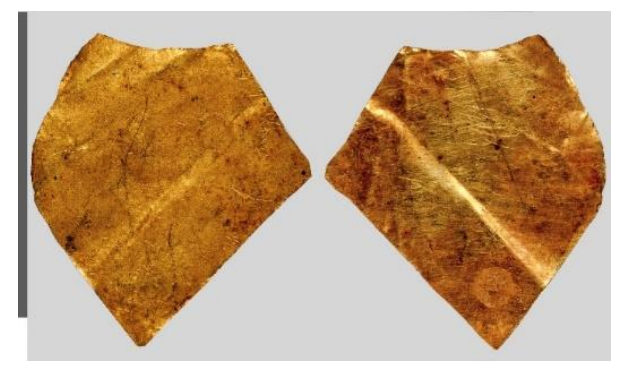

31. FOAIE DIN AUR. Aur, batere. $\mathrm{L}=1,40 \mathrm{~cm}, \mathrm{LA}=$ $1,00 \mathrm{~cm}, \mathrm{G}=0,04 \mathrm{~g}$. MNIR inv. nr. 9468 . Romboidală, cu marginile neregulate și vârfurile îndoite.

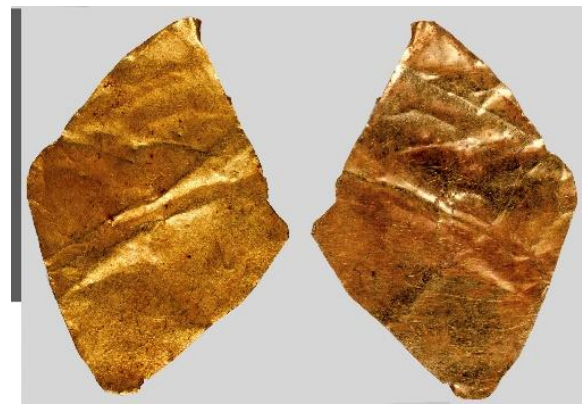

32. FOAIE DIN AUR. Aur, batere. $\mathrm{L}=1,40 \mathrm{~cm}, \mathrm{LA}=$ $1,00 \mathrm{~cm}, \mathrm{G}=0,04 \mathrm{~g}$. MNIR inv. nr. 9469

Romboidală, cu marginile neregulate, rupte și vârfurile îndoite, pliate.

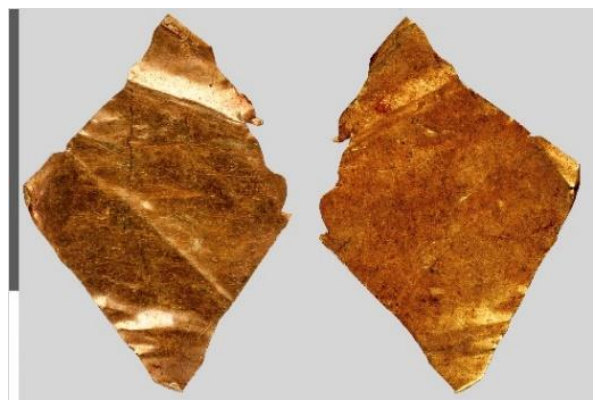

33. FOAIE DIN AUR. Aur, batere. $\mathrm{L}=1,12 \mathrm{~cm}, \mathrm{LA}=$ $0,50 \mathrm{~cm}, \mathrm{G}=0,03 \mathrm{~g}$. MNIR inv. nr. 9470. De formă nedefinită, cu marginile neregulate și îndoite.

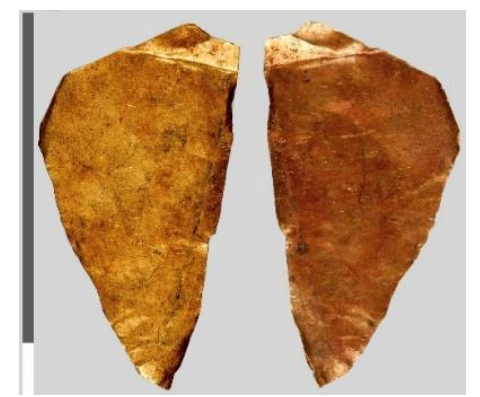

34. FOAIE DIN AUR. Aur, batere. $\mathrm{L}=1,20 \mathrm{~cm}, \mathrm{LA}=$
$0,55 \mathrm{~cm}, \mathrm{G}=0,04 \mathrm{~g}$. MNIR inv. nr. 9471. Romboidală, cu marginile neregulate, rupte, îndoită și pliată în zona mediană.

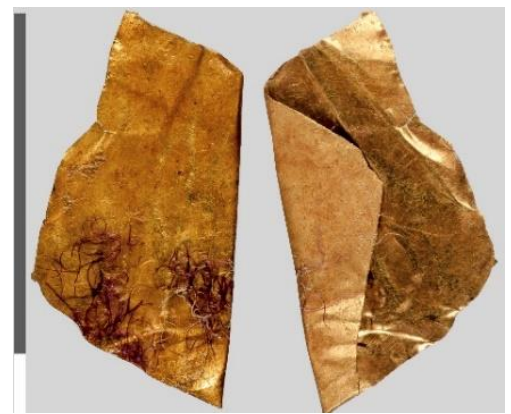

35. FOAIE DIN AUR. Aur, batere. $\mathrm{L}=1,02 \mathrm{~cm}, \mathrm{LA}=$ $0,70 \mathrm{~cm}, \mathrm{G}=0,03 \mathrm{~g}$. MNIR inv. nr. 9472. În formă de ,picătură”, cu marginile neregulate, vârful îndoit şi pliat.

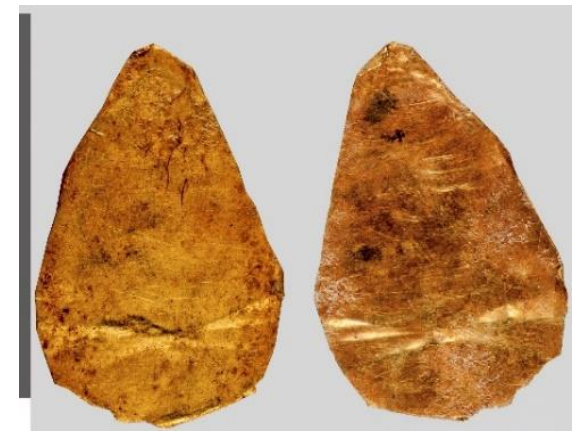

36. FOAIE DIN AUR. Aur, batere. $\mathrm{L}=1,43 \mathrm{~cm}, \mathrm{LA}=$ $0,92 \mathrm{~cm}, \mathrm{G}=0,04 \mathrm{~g}$. MNIR inv. nr. 9473. Romboidală, cu marginile neregulate, rupte, îndoită și pliată la unul dintre vârfuri.

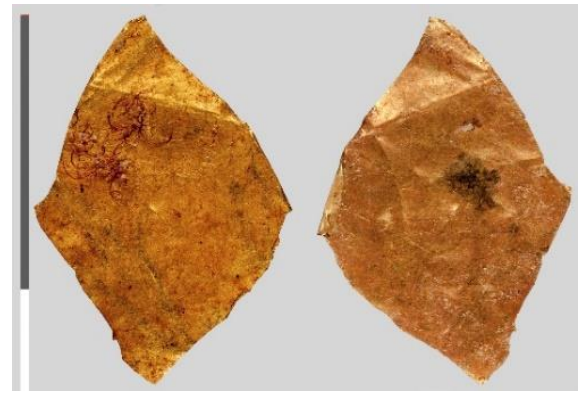

37. FOAIE DIN AUR. Aur, batere. $\mathrm{L}=1,45 \mathrm{~cm}, \mathrm{LA}=$ $1,09 \mathrm{~cm}, \mathrm{G}=0,05$ g. MNIR inv. nr. 9474 . Romboidală, cu marginile neregulate, rupte, îndoite și pliate.

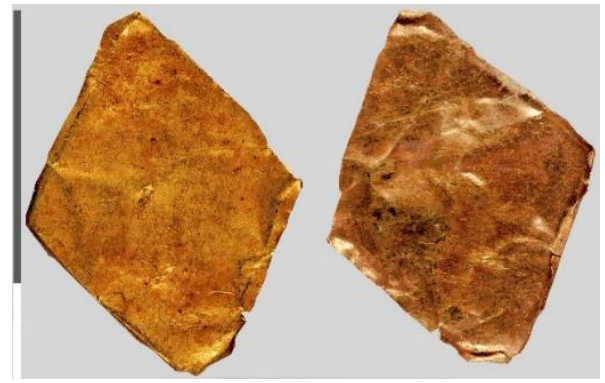


38. FOAIE DIN AUR. Aur, batere. $\mathrm{L}=0,92 \mathrm{~cm}, \mathrm{LA}=$ $0,67 \mathrm{~cm}, \mathrm{G}=0,02 \mathrm{~g}$. MNIR inv. nr. 9475 . Romboidală, cu una dintre margini pliată. La unul dintre vârfuri lipsește o parte din foaia de aur.

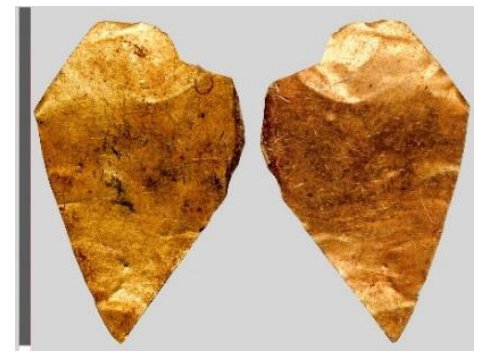

39. FOAIE DIN AUR. Aur, batere. $\mathrm{L}=1,02 \mathrm{~cm}, \mathrm{LA}=$ $0,60 \mathrm{~cm}, \mathrm{G}=0,02 \mathrm{~g}$. MNIR inv. nr. 9476 . În formă de ,picătură” cu o margine îndoită și pliată.

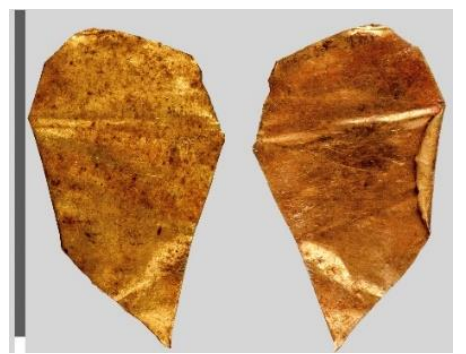

40. FOAIE DIN AUR. Aur, batere. $\mathrm{L}=0,91 \mathrm{~cm}, \mathrm{LA}=$ $0,60 \mathrm{~cm} \cdot G=0,02 \mathrm{~g}$. MNIR inv. nr. 9477. De formă nedefinită, cu marginile rupte, neregulate, îndoite și pliate.

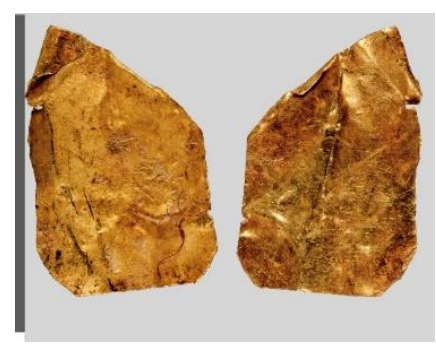

41. FoAIE DIN AUR. Aur, batere. $\mathrm{L}=1,10 \mathrm{~cm}, \mathrm{LA}=$ $0,70 \mathrm{~cm}, \mathrm{G}=0,03 \mathrm{~g}$. MNIR inv. nr. 9478. De formă nedefinită, cu marginile rupte, neregulate, cu un colț îndoit și pliat.

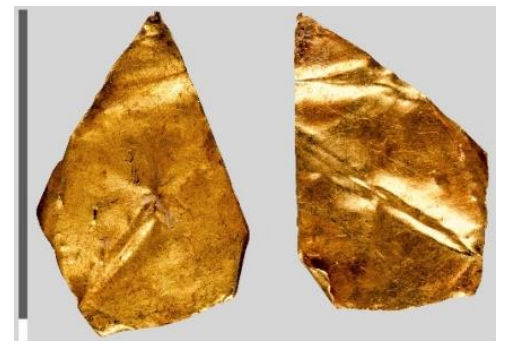

42. APLICĂ. Aur, batere, trefilare. $\mathrm{D}=0,30 \mathrm{~cm}, \mathrm{G}=$ 0,02 g. MNIR inv. nr. 9479. Buton semisferic din foaie din aur, cu un anou din fir de aur, lipit pe partea concavă pentru fixare.

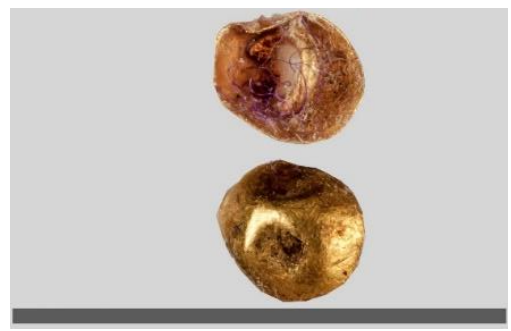

\section{BIBLIOGRAFIE}

Alexandrescu Vianu 1970

Allison 2013

Atanasov 2007

Aurul și Argintul

Antic al României 2014

Bâltâc 2011

Bulgan, Feugère 2007

Coche de la Ferté 1956

Covacef 1994

Covacef 2014
M. Alexandrescu Vianu, Les sarcophages romains de Dobroudja, RÉSEE 8, 2, 1970, p. 269-318

P. M. Allison, People and Spaces in Roman Military Bases, Cambridge University Press, 2013

G. Atanasov, Late Antique Tomb in Durostorum-Silistra, Pontica, XL, 2007, p. $447-468$

Aurul și Argintul Antic al României. Catalog de Expoziție. Muzeul Național de Istorie a României, R. Oanță-Marghitu (ed.), Râmnicu Vâlcea, 2014

A. Bâltâc, Lumea rurală în provinciile Moesia Inferior şi Thracia (secolele IIII p. Chr.), București, 2011

F. Bulgan, M. Feugère, Les Fibules Romaines du Musée de Gaziantep, în Anatolia Antiqua, XV, 2007, p. 215-224

É. Coche de la Ferté, Les Bijoux Antiques, Presses Universitaires de France, Paris, 1956

Z. Covacef, Grabfund aus Tomis (heute Constanța), în Goldhelm 1994, p. 184, 185, fig. 63.2, 63.7, 63.8, 63.9

Z. Covacef, Podoabe dintr-un inventar funerar. Secolul al II-lea p. Chr., în Aurul și Argintul Antic al României 2014, p. 430, 431, fig. 99.1.1, 99.1.2 
Damian, Bâltâc 2007

Deppert-Lippitz 2000

Donevski 1999

Donevski 2009

Facsády 2009

Филов 1915

Goldhelm 1994

Higgins 1980

Ilie 2014

Ivanov, Atanasov, Donevski 2006

Jeremić 2012

Lungu, Covacef, Chera 2012

Marshall 1911

Milovanović 2004

Oanță-Marghitu 2014

Oliver 1966

Petković 2010

Pirzio Biroli Stefanelli 1992

Popović 1996

Popović 2010

Riha 1994

Ruseva-Slokoska 1991

Știrbulescu 2007

FOTO: ing. MARIUS AMARIE
P. Damian, A. Bâltâc, The Civil Roman Settlement at Ostrov - Durostorum, în Important Sites from the Pre-Roman and Roman Time on the Lower Danube Valley (4 ${ }^{\text {th }}$ century BC $-4^{\text {th }}$ century $A D$.), Istros, XIV, Brăila, 2007, p. 61-70

B. Deppert-Lippitz, A Late Antique Crossbow Fibula in The Metropolitan Museum of Art, Metropolitan Museum Journal, vol. 35, The University of Chicago Press, 2000, p. 39-70

P. Donevski, Jewelry and Ornamental Objects from the Tomb of Durostorum în P. Donevski, I. Popović, Gold and Silver Jewellery from the Durostorum Burials, Svistov, 1999, p. 17-91

P. Donevski, Archaeological investigations in Silistra (Durostorum), Buletinul Muzeului Județean Teleorman. Seria Arheologie, 1, 2009, p. 105-130

A. Facsády, Aquincumi Ékszerek. Jewellery in Aquincum, Patria Nyomda ZRt., Budapest, 2009

Филов Б., Римското съкровище отъ Николаево (Rimskoto sǔkrobiște otǔ Nikolaevo), în Izvestija Sofia, IV, 1914 (1915), p. 1-48

Goldhelm Schwert und Silberschätze. Reichtümer aus 6000 Jahren rümanischer Vergangenheit, Museum für Vor-und Frühgeschichte Archäologisches Museum, Frankfurt am Main, 1994

R. Higgins, Greek And Roman Jewellery, Second Edition, University of California Press. Berkley and Los Angeles, 1980

C. Ilie, Necropola romană de la Tirighina-Bărboși, Galați, jud. Galați, în Aurul şi Argintul Antic al României 2014, 461, fig. 106.3.1

6 R. Ivanov, G. Atanasov, P. Donevski, History of Silistra volume I. The Ancient Durostorum, Sofia, 2006

G. Jeremić, Late Antique necropolis Jagodin mala. Naissus in the Late Antiquity. The National Museum of Nis, 2012

V. Lungu, Z. Covacef, C. Chera, Bijuterii antice din aur din colecțiile Muzeului de Istorie Națională și Arheologie Constanța, Constanța, 2012

F.H. Marshall, Catalogue of the Jewellery, Greek, Etruscan and Roman in the Departments of Antiquities, British Museum, London, 1911

B. Milovanović, Earrings - Symbol of Femininity of Roman Ladies of Viminacium, Anodos. Studies of the Ancient World 3/2003, Trnava, 2004, p. 131-143

R. Oanță-Marghitu, Colier, Dobrogea, loc de descoperire necunoscut, în Aurul și Argintul Antic al României, 2014, 451, cat. 103

A. Oliver Jr., Greek, Roman and Etruscan Jewelry, The Metropolitan Museum of Art Bulletin, 1966, p. 269-284

S. Petković, Crossbow Fibulae From Gamizgrad (Romuliana), Starinar LX/2010, Beograd, p. 111-136

L. Pirzio Biroli Stefanelli, L'oro dei Romani: Gioielli di età imperiale. Il metallo: mito e fortuna nel mondo antico, L'Erma di Bretschneider, 1992

I. Popović, Les Bijoux Romains du Musée National de Beograd. II Les bijoux d'or, Musée National, Begrade. Belgrade, 1996

I. Popović, Gold And Silver Jewelry From Central Balkan Provinces of Roman Empire, Histria Antiqua, 19/2010, p. 55-64

E. Riha, Die römische Fibeln aus Augst und Kaiseräugst. Die Neufunde seit 1974, Römermuseum Augst, 1994

L. Ruseva-Slokoska, Roman Jewellery. A Collection of the National Archaeological Museum - Sofia, Publishing House of the Bulgarian Academy of Sciences, Sofia, 1991

Ch. Știrbulescu, Un sarcofag descoperit în com. Ostrov, jud. Constanța, Pontica, XL, 2007, p. 283-306 


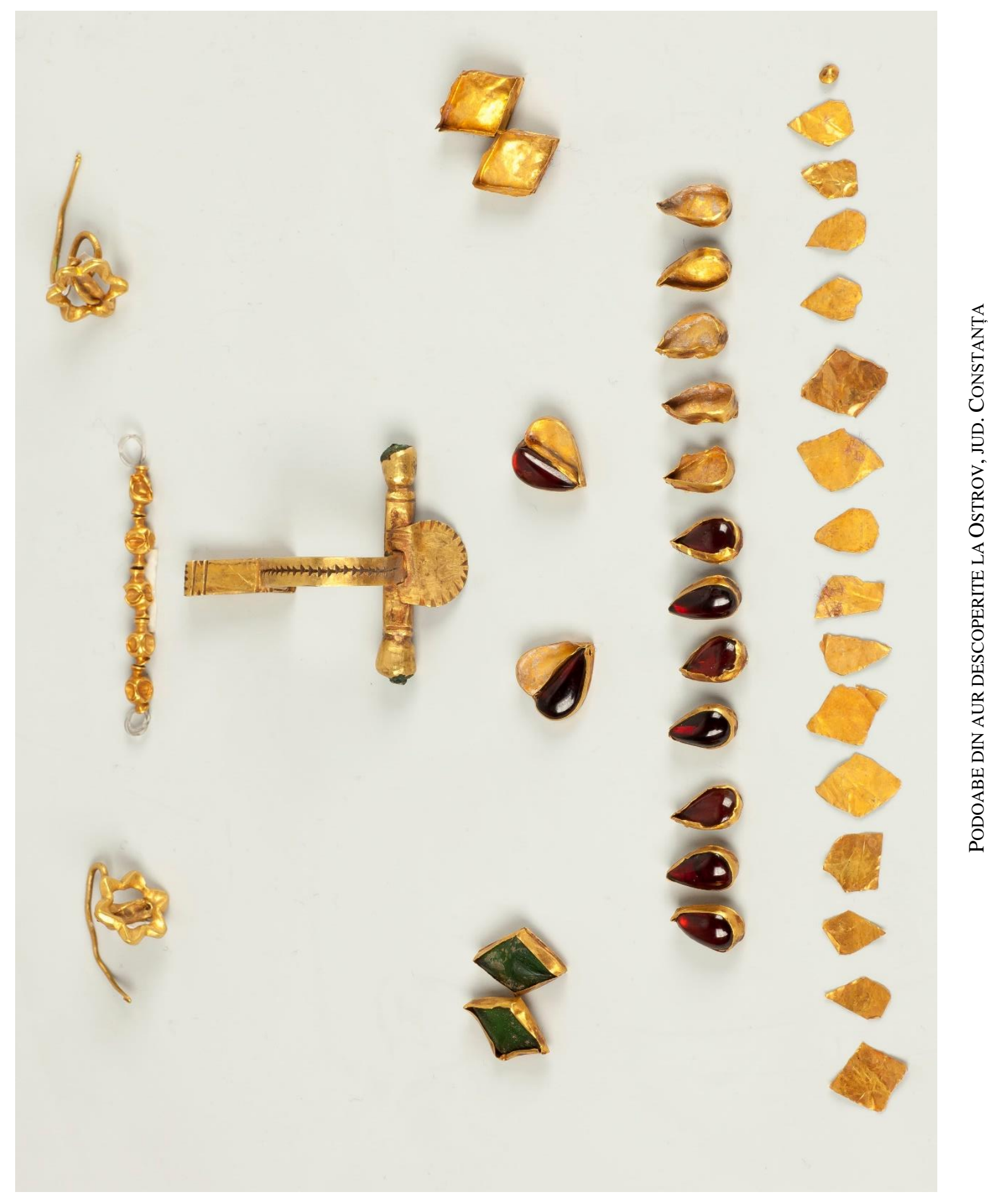

